NBER WORKING PAPER SERIES

LIFTING THE CURSE OF DIMENSIONALITY:

MEASURES OF THE LABOR LEGISLATION CLIMATE IN THE STATES DURING THE PROGRESSIVE ERA

\author{
Price V. Fishback \\ Rebecca Holmes \\ Samuel Allen \\ Working Paper 14167 \\ http://www.nber.org/papers/w14167
}

\author{
NATIONAL BUREAU OF ECONOMIC RESEARCH \\ 1050 Massachusetts Avenue \\ Cambridge, MA 02138 \\ July 2008
}

Price V. Fishback is the Frank and Clara Kramer Professor of Economics at the University of Arizona and a Research Associate with the National Bureau of Economic Research, Department of Economics, University of Arizona, Tucson, AZ 85721 (520-621-4421, pfishback@bpa.arizona.edu). Rebecca Holmes is Director of Economics, Cox Communications, 1550 W. Deer Valley Rd, Phoenix, AZ 85027, (phone 623-328-3983, Rebecca.Holmes@ cox.com. Samuel Allen is an Assistant Professor of Economics at the Virginia Military Institute. Department of Economics and Business, 341 Scott Shipp Hall, Virginia Military Institute, Lexington, VA 24450 (540-464-7061, AllenSK@ vmi.edu). We would like to thank Robert Margo, Paul Rhode, Andy Daughety, Gerald Friedman, Claudia Goldin, Lawrence Katz, Sumner LaCroix, Jeremy Atack, Shawn Kantor, Bill Collins, Ronald Oaxaca, Joshua Rosenbloom, Lou Cain, and Tom Weiss for helpful comments. Keith Poole deserves special thanks for his generosity in sharing information about and guiding us through the process of using the optimal classification technique for the COORDINATE measures. The views expressed herein are those of the author(s) and do not necessarily reflect the views of the National Bureau of Economic Research.

NBER working papers are circulated for discussion and comment purposes. They have not been peerreviewed or been subject to the review by the NBER Board of Directors that accompanies official NBER publications.

(C) 2008 by Price V. Fishback, Rebecca Holmes, and Samuel Allen. All rights reserved. Short sections of text, not to exceed two paragraphs, may be quoted without explicit permission provided that full credit, including $\odot$ notice, is given to the source. 
Lifting the Curse of Dimensionality: Measures of the Labor Legislation Climate in the States During the Progressive Era

Price V. Fishback, Rebecca Holmes, and Samuel Allen

NBER Working Paper No. 14167

July 2008

JEL No. J18,K31,N31,N32,N41,N42

\begin{abstract}
$\underline{\text { ABSTRACT }}$
One of the most difficult problems in the social sciences is measuring the policy climate in societies. Prior to the 1930s the vast majority of labor regulations in the U.S. were enacted at the state level. In this paper we develop several summary measures of labor regulation that document the changes in labor regulation across states and over time during the Progressive Era. The measures include an Employer-Share-Weighted Index (ESWI) that weights regulations by the share of workers affected and builds up the overall index from 17 categories of regulation; the number of pages of laws; appropriations for spending on labor issues per worker; and two nonparametric COORDINATES that summarize locations in a policy space. We describe the pluses and minuses of the measures, how strongly they are correlated, and show the stories that they tell about the changes in labor regulation during the progressive era. We then provide preliminary evidence on the extent to which the labor regulation measures are associated with political and economic correlates identified as important in histories of industrial relations and labor markets.
\end{abstract}

Price V. Fishback

Department of Economics

University of Arizona

Tucson, AZ 85721

and NBER

pfishback@eller.arizona.edu

Rebecca Holmes

Cox Communications

rebecca.holmes@cox.com
Samuel Allen

Virginia Military Institute

341 Scott Shipp Hall

Lexington, VA 24450

allensk@vmi.edu 


\section{Lifting the Curse of Dimensionality: Measures of the Labor Legislation Climate in the States During the Progressive Era}

One of the most difficult problems in the social sciences arises when trying to develop summary measures of the policy climate in societies. Government regulation, constitutions, and legal structures are often messy and not easily quantified. In modern societies they often involve thousands of pages of laws, court decisions, and administrative decisions within the government, as well as in external assessments by politicians, lawyers, and scholars. Yet summary measures that isolate the key components of the policy climate are necessary for developing an understanding of how the measures were adopted and their impact on societies.

Over the past few decades, as statistical analysis has begun to play an increasing role in the social sciences, scholars have developed a wide variety of quantitative measures of features that do not lend themselves easily to measurement. For example, Jack Walker (1969) developed an "innovation score" to describe the changes in state government policies before 1965 for 88 different programs. ${ }^{1}$ Poole and Rosenthal $(1991,1997,2000)$ and Poole (2005) use measures of legislative voting to develop "spatial coordinates" that describe the typical positions in the public policy space of the U.S. Congress and the British Parliament. Alternative measures of voting ideology have been created during the same era by Berry, Ringquist, Fording, and Hanson (1998). Numerous scholars have found this work useful for estimating the influences on policy and the influence of policy on social factors. ${ }^{2}$

Scholars and policy makers interested in the study of the importance of Democracy, the extent of market economies, and the protection of individual freedoms have developed indices like the Index of Economic Freedom, the Freedom House scores, and the rule-of-law. These 
have been used by a large number of social scientists in analyzing the determinants of these policies and their impact on economic growth and other measures of the success of society. ${ }^{3}$

Nearly every historian of labor relations and labor markets examines the role of governments in determining (or not determining) rules for collective action, arbitration of disagreements between workers and employers, and standards for the terms of employment. ${ }^{4}$ Whether the work is narrative or quantitative in nature, nearly all grapple with issues about how best to describe the nature of government policies. ${ }^{5}$

To aid businesses, unions, and workers understanding of the labor regulation climate during the Progressive Era, the U.S. Commissioner of Labor and then the Bureau of Labor Statistics published volumes that described the text of all of the labor statutes on the books in the states. In the 1930s John R. Commons and his Associates, in particular, Elizabeth Brandeis, offered detailed assessments of these policies in their History of Labor in the United States. ${ }^{6}$ Having worked with these sources and the original statutes and studied many court decisions in the course of studying workers' compensation and other labor issues, we have seen the great diversity and breadth in labor regulations. This diversity sometimes gets lost in the analysis of labor legislation during the Progressive Era because most scholars have sought to focus on specific policies, like workers' compensation or child labor laws. Recognizing the interactions of these laws with the broader regulatory climate is likely to be important, however, because the broader setting likely influenced the adoption and impact of the specific policies.

Our goal in working on this project has been to develop several summary measures of the overall labor regulation climate at the state level during the Progressive Era. We offer several different types of measures to try to capture different aspects of the regulatory climate 
and to check the degree to which these measures are correlated with each other. The measures are used to show the expansion of labor regulation both within and across states over the course of the Progressive Era. We conclude with some preliminary analysis of political and labor market correlates that influenced the spatial and geographic variation in the measures over time.

Another goal of the project is to give more recognition to the extent of labor legislation at the state level that existed before the federal involvement that arose during the New Deal. Labor historians are well aware of the role played by the states in regulating labor markets in the early 1900s. Based on our observations at conferences, many social scientists who study the modern era are not. By creating measures of labor market regulation that can be aggregated to the national level, we hope that the measures will cause such social scientists to be aware of the extent of regulation in place before the national government got involved.

\section{HISTORICAL BACKGROUND}

Increasingly large numbers of workers entered the industrial sector between the end of the Civil War and the 1920s. The adoption of new machinery and new methods of organizing work led to an expansion in the size of workplaces. Workers who entered the workforce in the 1870s experienced dramatic changes in the nature of workplaces. Many started in agriculture or in small hand manufacturing operations where there were strong personal relations between the worker and the employer. As the decades passed, many ended up in larger operations with more impersonal relationships.

Meanwhile, hundreds of thousands of immigrants arrived and began working in the mines and many of the leading industries. Many workers felt that they had lost a significant 
degree of control over their work situation. They had less interaction with the owners of the firm and their employment situation could be threatened by national and international market forces over which even their employer had no control. A number of workers responded by joining unions, including unions with broad coverage like the Knights of Labor in the late 1870 s and the $1880 \mathrm{~s}$, and the more narrowly construed unions focused on their craft or industry.

Another response was for workers to join with a wide range of social reform groups to seek more state regulation of the workplace. Workers were not always opposed by employers when they sought regulations. In fact, Fishback (1998), among others, has suggested that progressive employers, often larger and more likely to be unionized, supported new regulations that codified their own practices or cost them little to put in place. He argues that many of the progressive era labor regulations were enacted when leading employers joined workers and reformers in pushing for new regulation. One sign that this was likely to be true was the lack of success of workers and reformers in their attempts to push for state health insurance and unemployment insurance, two policies actively opposed by many large employers. ${ }^{7}$

Nearly all the regulatory activity during the Progressive Era took place in state governments. $^{8}$ As a result, the national regulatory environment often looked like a patchwork quilt that was constantly being reworked. One reason was that some activities, like coal mining, took place in half or fewer states. For more general regulations, like workers' compensation, the political structure and the strength of interest groups in the economy varied substantially from state to state, leading to differences in the timing of adoption of the laws.

The range of issues addressed was impressive. As seen in Table 1, many of the mining states were early adopters of rudimentary mining regulations that called for the filing of maps 
and provision of basic ventilation between 1869 and 1880. Simultaneously at the behest of the nascent union movement many states established bureaus to collect labor statistics, often in the form of surveys of workers. By the 1880 s some states had began putting more teeth in the regulations by providing for inspectors of boilers, factories, and mines. When the inspectors found violations, the state attorney general or prosecutors would then take the employer to court to determine the extent of the defense and the fine to be paid. As the pressures for collective bargaining arose in the late 1870s and 1880s, a number of states established mediation, arbitration, and conciliatory bodies to aid in settling strikes (Currie and Ferrie 2000). The struggles between striking workers and employers carried into the legislature as each side sought support from the state in establishing the rules for bargaining. Some states passed laws that promoted unionization by outlawing "yellow dog" contracts and protecting union trademarks and labels. On the other hand, other states seemed bent on limiting unionization with the passage of anti-enticement laws and laws that limited picketing and were specifically targeted at reducing intimidation of non-union workers. Meanwhile, a number of professionals sought forms of occupational licensing that can be seen as attempts to control the quality of service provided and/or to raise the incomes of the licensed professionals by limiting entry. ${ }^{9}$

Various states legislated limits on wages and hours of male workers, although such laws were so broadly written as to have little meaning or were struck down by the courts. Limits established for child labor and women's hours were more successful. Perceptions of increased dangers associated with industrialization caused states to pass laws regulating workplace safety and developing new rules for the compensation of injured workers. 
Using the volumes published by the U.S. Commissioner of Labor $(1896,1904,1908)$ and later the Bureau of Labor Statistics (1914, 1925), Commons and Associates (1966), and the annual or semiannual state reports on new statutes passed by the legislatures, Rebecca Holmes $(2003,2005)$ accumulated a database that covers each year from 1900 through 1925 and identifies which states had each of 135 different labor laws for her dissertation. In the course of pursuing other projects, we have added information on the total number of pages devoted to all labor laws in the states, and the extent of state legislature's appropriations for spending on the administration and enforcement of their labor laws. The goal of this paper is to use this information to develop measures of the changing labor regulatory climate in the states during the Progressive Era.

The presence of so many types of laws would have been considered a blessing to those who succeeded in getting them passed. However, someone seeking to develop a broad picture of the regulatory climate faces the curse of dimensionality. We seek to lift the curse by coming up with a series of summary measures of the regulatory climate that allow for summary comparisons both across states and time.

In a recent paper in a volume honoring Thomas Weiss, we began to lift the curse by creating a series of indexes that involved a simple count of the laws, an index that reweighted the laws by putting them into specific categories of laws and then summing across categories, and then indices that weighted laws by the share of the workforce affected by the laws (see Holmes, Fishback, and Allen 2008). We found that all of these measures were highly correlated with each other. Cross-sectional correlations for the 48 states between the measures were above 0.96 in 1919, 0.97 in 1909, and 0.96 in 1899. Correlations of the change over time 
in the indices were above 0.89 for the change from 1899 to 1919 , above 0.87 for the change from 1899 to 1909 , and above 0.89 for the change from 1909 to 1919.

The most conceptually appealing of the indices in that paper was the EmploymentShare-Weighted Index (ESWI). In the index we divided the laws into 17 categories and each of the laws within the categories are weighted by the share of workers directly covered by the law. In this way multiple laws dealing with the same issue are not given too much weight. Nor were laws specific to a subset of the workforce given weight that exceeded their share of the workforce.

In this paper we compare the ESWI with other measures of labor legislation, including the number of pages devoted to labor laws, the state appropriations for administering and enforcing the labor laws, and a pair of COORDINATE measures that use the information on over 130 labor laws to examine how closely the labor laws of each state match each other. No single measure fully captures the labor climate. Scholars will likely differ on how much weight to give to each law in the ESWI. There are so many laws that a debate over weights could be endless. Page numbers and labor spending provide alternative ways of measuring the breadth and depth of the laws and enforcement and the COORDINATE measures offer an alternative check that is largely derived from a data-mining exercise.

Our goal is to provide all of these measures and check their comparability to see if they describe similar patterns over time and across states. We chose these measures because they seemed a reasonable start. The complete set of data on the laws will be posted at Price Fishback's website in the medium run and eventually the ICPSR website, so that other scholars can develop their own indices if they find the ones described in this paper do not meet their research goals. Readers should recognize one caveat on the use of the information that will be 
posted. Scholars focusing on a specific law or set of laws should see the information as a starting point for their research. We have no illusions that we have captured all of the subtleties of particular laws and careful reading of the laws to further refine the measures is advised when analyzing each specific law.

\section{CONSTRUCTING THE ESWI}

The ESWI is constructed with the laws listed in Appendix Table 1 compiled from the reports on "Labor Laws in the United States by the U.S. Commissioner of Labor (1896, 1904, 1908) and the Bureau of Labor Statistics $(1914,1925) .{ }^{10}$ The laws are divided into 17 categories: Workplace activity regulation, which includes specific regulations for factories, mines, railroads, street railroads, and limits on occupational entry; Hours regulations for women, children and some groups; Workplace activity regulation for women and children, which are additional regulations of workplace activity specifically focused on women and children and thus kept separate; Employer liability and workers' compensation; Steam boiler inspections; Unionization and Bargaining, which include positive values for laws that favored unions and negative values for those making unionization more difficult; Laws that prohibit bribery and coercion and protect political freedoms; the presence of a Department of Labor or Bureau of Labor Statistics; the presence of a State Board of Arbitration, Mediation, or Conciliation; the presence of a Rehabilitation Commission; the presence of an Industrial Commission, which is kept separate from Departments of Labor because some commissions had rule-making authority not given to labor departments; Free Employment Offices; AntiDiscrimination; Payday Regulations; Holiday Regulations; Minimum Wage Regulations; and Miscellaneous Regulations. 
Within each law category $j$ we develop an Employment Share-Weighted Index (ESWI) that is designed to sum to a maximum value of one for that category. We chose the value of one as a maximum to avoid giving too much weight to a law that is just one of many in a category like workplace activity. In this method the categories of laws are given equal weight.

A law within any category is weighted by the share of the nonagricultural workforce covered by the law as of 1900 . If the law deals only with miners, for example, it is therefore given a much smaller weight than if it deals with all workers. The mathematical formula for the ESWI within category $j$ is

$$
\mathrm{ESWI}_{\mathrm{jst}}=\sum\left(L_{i j s t k} * \mathrm{~S}_{\mathrm{s} 1900 \mathrm{k}}\right) / m_{j} \text { for } \mathrm{i}=1 \text { to } \mathrm{m}_{j} \text {. }
$$

for the state $s$ in year $t$. The law $L_{i j s t k}$ refers to the ith law in category $j$ in state $s$ in year $t$ covering the $k$ th category of workers. If the law is in force, $L_{i j s t k}$ has a value of one; if not, it takes a value of zero. As an example of how an actual law fits the subscripts, consider bakery regulation. The bakery regulation law (i) comes under the category Economic Activity Regulations $(j)$ in West Virginia $(s)$ in $1919(t)$ for bakers $(k)$.

To take into account the fact that the bakery regulations only cover bakers and not the rest of the workforce, we multiply the law by the share of nonfarm workers in baking $(k)$ in state $s$ in the year $1900\left(S_{s 1900 k}\right)$. The employment weight is one when the $k$ subscript refers to regulations that apply to all nonagricultural workers. ${ }^{11}$ The weights for each employment category $k$ in each state are based on information from the 1900 census on the number of gainfully employed men, women, and children in occupations in 1900 and the average numbers of each type employed in various manufacturing industries in 1899 (U.S. Bureau of Census, 1904, 1902 volumes 7 and 8, and Haines (ICPSR 2896)). We chose the 1900/1899 weights to reflect the situation in the first year for which we make cross-state comparisons of the labor 
laws. We then continue to use the 1900/1899 weights for all other periods to avoid feedback problems where changes in regulation are causing changes in the shares of people in industries. This weighting still potentially has some problems with feedback effects for the $1899 \mathrm{ESW}$ index. We chose this period to develop the employment shares because we thought that the situation in 1890 would not be reflective of the employment in the $20^{\text {th }}$ century because the late 1800 s were a period of industrial change. As another way to avoid problems with specific state distributions being influenced by the labor laws in the state, we have also developed an index where the weights are based on the national distributions across occupations and industries (and thus the s subscript is dropped for the employment share). It turns out that the indices based on the national employment weights are very strongly correlated with the indices based on the state employment weights.

In calculating the employment shares we use as the denominator an "employment base" composed of the number of gainfully employed in trade, transport, manufacturing, and mechanical pursuits from the 1900 Census of Occupations. These categories include miners and construction workers and were the focus of nearly all of the labor regulations. The denominator probably overstates the number of people likely to be affected by regulation because workers in wholesale and retail trade were less affected by the labor regulations. The workers left out of the base are professional workers, domestic and personal service workers, and agricultural workers. The agricultural, domestic, and personal service workers were often explicitly left uncovered by many regulations. Some professionals were licensed and we do include in the numerator a licensing measure for specific occupations but the workers in these occupations account for a very small share of the professionals and an even smaller share of 
workers subject to regulation; therefore, we don't see that their absence in the denominator will be a serious problem. ${ }^{12}$

After weighting the law by the employment share, we sum the values for the laws in category $j$ and divide by the number of laws in that category $\left(m_{j}\right)$. This insures that the maximum value for category $j$ is one. As seen in Appendix Table 2, the number of laws $\left(m_{j}\right)$ in the Workplace Activity category $(j)$ is 38 , so the sum of all of the laws after they have been weighted by their employment share is then divided by 38 . Given that the laws are weighted by the share of people employed and some of the laws were likely to be focused on only subgroups of workers, the ESWI for category $k$ could be substantially less than one.

The ESWI for two law categories are based on measures other than pure law counts. In the employer liability and workers' compensation category, we used Fishback's and Kantor's (2000) expected benefits measures as a percentage of annual income as the basis for the index. For years when workers' compensation was in place the expected benefits were calculated using the specific parameters for the laws. The typical workers' compensation value was above 1 and ranged as high as 2.82. For years in which no workers' compensation laws were in force, we started with a ratio of expected benefits to annual income of 0.5 based on Fishback and Kantor's comparisons of expected payouts under employer liability and workers' compensation. The expected benefit/income ratio for states without workers' compensation was then adjusted upwards from 0.5 in states where the actuaries suggested higher employer liability premiums to insurers based on employer liability laws that would lead to higher payouts to workers. The expected benefit/income ratio was lowered from 0.5 in states where lower premiums were suggested by the actuaries. The variable is expben10 in the wcdata.xls Excel spreadsheet under Workers' Compensation Project Data at 
http://www.u.arizona.edu/ fishback// used in March 2006. Descriptions of the construction of the variable are in Fishback and Kantor (2000, Appendix B) and at the same website. To index the values we divided by the maximum value of 2.82 so the value would range between zero and one.

In the male-hours category, a number of states passed general maximum hours laws in the late 1800 s that stated that the official work day was an eight-hour day but typically added the proviso, "unless specified otherwise by contract." We gave them a maximum value of 0.1 . The U.S. Bureau of Labor Statistics suggested that these laws had little effect because of the contracting out clause and lack of enforcement. The laws were weakened further after the U.S. Supreme Court in 1905 declared that New York state regulation of bakers' hours violated the U.S. Constitution. ${ }^{13}$ We decided to assign them some positive value because some employers might have routinely followed the law even without much enforcement and because the laws likely triggered some negotiations of contracts that might have led to hours reductions. Once the new hours structure was in place, these employers might have decided to leave them in place even after the 1905 decision. $^{14}$

To calculate the overall ESWI for a state-year, we take the ESWI for each category $j$ and sum across all seventeen categories and then divide by $17 .{ }^{15}$ Thus, the formula for the overall ESW Index for state $s$ in year $t$ in year

$$
\begin{aligned}
& E S W I_{s t}=\sum E S W I_{j s t} / 17 \text { for } \mathrm{j}=1 \text { to } 17 \\
& =\sum\left(\sum\left(L_{i j s t k}{ }^{*} \mathrm{~S}_{\mathrm{s} 1900 \mathrm{k}}\right) / \mathrm{m}_{\mathrm{j}} \text { for } \mathrm{i}=1 \text { to } \mathrm{m}_{\mathrm{j}}\right) / 17 \text { for } \mathrm{j}=1 \text { to } 17 .{ }^{16}
\end{aligned}
$$


The final value has a maximum value of one when all workers are covered by every phase of regulations that workers favored. If there were no laws except anti-union laws, the value could fall below zero.

The maps in Figure 1 shows the ESWI for the states in 1899, 1909, 1914, and 1919, respectively. The scale for each of the maps is the same and is based on putting states into 5 roughly equal groupings based on the ESWIs in 1919; therefore, the changes over time can also be seen. Figure 2 shows the information in a scatter plot with more precise values visible for the ESWI for 1899 and 1919. The highest ESWIs in 1899 were above 0.4 in Pennsylvania and New Jersey, which collectively had the broadest range of industries. Several Midwestern states, Colorado, Massachusetts, and Montana were next in line.

By 1909 New York had become the leader with an ESWI near .5, while Indiana, Colorado, Massachusetts, Wisconsin, Minnesota, Indiana, Ohio, Pennsylvania were close behind (see Figure 2). By 1919 Massachusetts had surpassed New York, which had stayed in roughly the same position. The academic and political activity by institutional economists like John R. Commons and Richard Ely had contributed to Minnesota and Wisconsin being close behind. Also, among the leaders were Pennsylvania, Ohio, and California. The one state that seems to have lagged behind was New Jersey.

In general, the rankings of the states with respect to the ESWI are pretty stable over time. The upward slope of the majority of spots on scatter plots in Figure 2 show that many of the states who had more labor regulation circa 1899 tended to also rank highly in 1919 . The correlations across time of the ESWIs in Table 2 are all positive and above 0.725 .

The changes in labor legislation shed some different light on the labor regulatory activities in New York. Recent media strongly states that much of the labor legislation of the 
Progressive Era was stimulated by the Triangle Shirtwaist Factory Fire, in which dozens of women textile workers died in New York City in March 1911. The rise in the ESWI for New York between 1899 and 1909 and the relatively small change in the ESWI between 1909 and 1919 suggest that there was a great deal of interest in labor legislation in New York well before the Fire. The Triangle Shirtwaist Factory had been inspected and no fines imposed within the prior month even though it was in violation of several of the existing laws with respect to fire escapes and other fire prevention measures. Many of the legislative changes that followed the Fire were attempts to tighten these laws and enhance enforcement. The state did eventually increase its spending on inspections, but the increase in inspectors was small relative to the number of inspections that would have been required for all factories to be inspected annually. Scholars have found complaints in New York newspapers after the new laws were passed that many of the laws were still largely ignored and that inspections continued to be rare events. ${ }^{17}$

\section{PAGE COUNTS}

Some scholars have experimented with using page counts as a measure of labor regulation (for example, see Mulligan and Shleifer (2004)). The argument is based on the notion that states with more extensive laws would have to describe them in depth. There are certainly flaws in this simple method. Laws with negative consequences for labor are given the same page value as those with positive consequences. The length of the legal text also might overstate its power. A law banning all labor by children under 16 and appropriating one million dollars to hire 500 people to enforce it can be stated succinctly. Meanwhile, it might take a dozen pages to describe a set of regulations designed to make workplaces safer for 
children. The first does far more to guarantee that a child under 16 is safe from manufacturing risk.

In other situations states might adopt specific laws for four different industries, while another state adopts a general law with broader coverage. This happened with hours laws in a number of states, and the broader laws have greater effect even though the text of the laws is shorter.

The BLS reports on the text of laws made it relatively easy to develop page counts in 1904, 1907, and 1914 when the volumes were published. The reports do not include information on the workers' compensation laws, but this will only affect the measure for $1914 .^{18}$

As can be seen in Figures 3 and 4, Pennsylvania is far and away the leader in page counts throughout the early twentieth century with many of the same states with high ESWIs following behind. Figure 3 shows maps of page counts for the states with the scale used in the legend based on a roughly equal distribution of states in five categories as of 1914 . The stability of state rankings over time is shown in the scatter plots for the page counts in 1904 and 1914. Most states increase the text of their labor legislation even though workers' compensation is not included in the 1914 page counts. The states held more tightly to the relative rankings over time than for the ESWI. The correlations in Table 2 for the page counts are above .9 for all comparisons across the 18 years covered. Notice that there appears to be more clumping of states around the same text levels in both periods than we saw with the law sum and ESW Index.

The situations for Pennsylvania and New York help illustrate the possible overstatement of regulation from counting pages when there are laws written for specific 
industries. Pennsylvania probably had the most diverse coverage of American industries of any state. ${ }^{19}$ They wrote separate and specific safety regulations for bituminous coal mining, anthracite coal mining, and the factories. The state ranks near the top in the ESW Index comparisons, but the large body of text devoted to specific industries is what makes them a strong outlier here. New York had similar breadth of coverage of industries but had almost no mining industry and therefore has page counts much closer to the counts in the other states.

\section{EXPENDITURES BY STATES ON LABOR ISSUES}

The presence of laws offers only one indication of the regulatory climate for labor markets in the states. Laws on the books have little impact if they are not enforced and labor administrators and inspectors are likely to have more influence over labor markets with more resources available to them. As an additional measure of the labor regulatory climate, we have collected information from the legislative statutes on the appropriations for the state labor department, board of arbitration, free employment offices, mining inspection, boiler inspection and other administrations related to labor markets. ${ }^{20}$ To date, we have coverage for all states in the years 1903 through 1916. We then calculate a measure of state labor spending in 1967 dollars per person employed in mining and manufacturing. The denominator does not include groups of gainfully employed workers who typically were not subject to labor regulation: agricultural pursuits, domestic and personal service. Railroad workers, street railroad workers, and professionals were affected by some of the labor regulations, so the use of only mining and manufacturing as the denominator overstates the spending per worker covered to some degree. It turns out, however, that the relative ranking of states is generally the same when we try different groups of workers in the denominators. ${ }^{21}$ 
The spending per worker serves as an index that simultaneously measures the coverage of the legislation and the extent to which it is enforced. Enforcement is still imperfectly measured because enforcement of many safety regulations often relied on the courts so that violations might have been uncovered but not punished (see Fishback 2006; Graebner 1979). ${ }^{22}$ Complete bans or bright-line rules might also require little in the way of enforcement or administration because violations are so obvious. Finally, regulations tend to involve a fixed cost of basic administration. In states with regulation and small industrial workforces, the spending per worker measure might overstate the strength of the regulatory climate.

The spending measure tells a somewhat different story than the page and law sum and index measures. The correlations between time periods reported in Table 3 are weaker, as the correlation of the 1916 and 1903 measures are much lower at 49 than the correlations for any of the other measures in the Table. The correlations between the measures for 1903 and 1909 and again for 1909 and 1916 are also somewhat weaker at 0.74 and 0.78 .

The maps in Figure 5 and scatter plots in Figure 6 show many similarities to the comparisons for the other measures. In general, high values of labor spending per worker were probably associated with more extensive labor regulation. Massachusetts, New York, Indiana, Ohio, Colorado, Pennsylvania and Minnesota all rank relatively high as they did in the other rankings.

A number of western states are scattered around the outer range of the scatter plot in Figure 6. The locations came about through a combination of fixed costs of setting up labor regulations, small numbers of industrial workers, and generally better labor conditions in the west. Most of the western states were relatively new to industrialization and had relatively small numbers of industrial workers. To attract workers western employers tended to pay 
higher wages. Roughly 20 to 40 percent of the nonagricultural employment base in the western states was in mining, which was among the most dangerous of activities. The employers' desire to attract workers and to limit collective action by active western unions led them to support the adoption of mining and other regulations in territorial and state legislatures, a trend actively encouraged by reformers and unionized workers. At the same time establishing and administering regulations required significant annual fixed costs and the hiring of inspectors often came in increments of $\$ 1000$ to $\$ 2000$. Therefore, as the number of industrial workers in the West increased, the fixed costs of regulation were divided by an increasing number of workers, and the spending per worker declined. This helps explain the declines in real spending associated with Colorado, North Dakota, Idaho, and Wyoming. Nevada, and Washington were relative latecomers to industrialization and thus by 1916 they may have been situated in the position where these other western states were sitting in the late 1890s.

West Virginia and Pennsylvania are similar to the western states in that mining, coal in this case, was a leading industry. Coal miners accounted for a high percentage of the employment base in both states, higher in West Virginia. Because West Virginia and Pennsylvania were further advanced in terms of employing miners and other industrial workers in 1903 and 1916, our sense is that the rise in spending per worker in Pennsylvania and West Virginia likely reflects more of an increase in intensity of labor regulation than it does for Nevada, and Washington. 
Our measures thus far have been designed to try to capture the intensity of the regulatory climate. The various measures each have advantages and disadvantages based on the weighting given to laws and allocation of spending. The weightings have been explicitly designed and scholars may have alternative a priori interpretations of the regulations that would lead them to reweight the laws.

Another route is to take an agnostic approach and use nonparametric methods to measure the similarities in portfolios of policy choice across states. The method we use is a version of the Optimal Classification method that Keith Poole and Howard Rosenthal have

used to describe voting patterns in Congress. ${ }^{23}$ The method is designed to establish coordinates in a "policy space" for which no explicit dimensions are established in advance. The COORDINATE measures we develop essentially show which states have the combination of policies that look the most alike. Since we have not pre-assigned any specific weighting scheme in advance, the COORDINATE measures can serve as a useful robustness check of the other measures.

In other settings scholars have offered interpretations of what the dimensions of the policy space mean, similar to the way that social scientists have interpreted the factors that come out of factor analysis. Poole and Rosenthal (1997, 1994, 1993, 1991), for example, use their spatial coordinates, called NOMINATEs, to show the degree to which Congressmen voted in similar ways on a large number of policy issues. They found that after examination of voting patterns for a large number of issues that the similarities in voting patterns between Congressmen can be shown relatively effectively by two dimensional coordinates. Although, their spatial coordinate method does not assign any interpretation to the vertical and horizontal measures, Poole and Rosenthal assigned ad hoc interpretations to the dimensions by comparing 
the spatial locations to attributes of the Congressmen, the attributes of their constituents and the way people voted on a set of laws.

Tomas Nonnenmacher (2002) has applied a nonparametric Binomial Unfolding technique, which is an updating of NOMINATE by Poole $(2000,2001)$, for a similar purpose to ours. Nonnenmacher's goal was to develop measures of location in policy space for the states based on the extent to which they adopted the laws collected by Jack Walker (1969) in his policy diffusion study. As was the case in Poole and Rosenthal's Congressional study, the spatial dimensions have no obvious interpretation from the data examined. Nonnenmacher applies interpretations to the relative rankings based on the extent to which they are correlated with socio-economic measures.

We estimated two COORDINATEs for each state in each year. In the sample for estimation we treated each state in each year as a separate observation and included an observation for each state for each year from 1896 through 1924. By performing the estimation in this way we developed COORDINATE measures that allowed comparisons both across states within the same year and also comparisons of the policy choices across time. For example, by pooling the data and treating Connecticut in 1896 as a separate observation from Connecticut in 1924, the COORDINATE measures could be used to compare the location of Connecticut in 1896 to another state like West Virginia in 1896 but also to Connecticut in 1924 or Virginia in $1920 .^{24}$

The changes over time in the two COORDINATE coordinates are shown in the maps in Figures 7 and 8 and in the scatter plots in Figure 9. As is the case with factor analysis and the Congressional voting analysis, there is no obvious interpretation of the dimensions of the coordinates without adding extra information. Some insights can be gained by examining the 
correlations with various types of laws. The COORDINATE ONE coordinate, the vertical coordinate in Figure 9 seems to be strongly associated with factory regulations, while COORDINATE TWO appears to be strongly associated with mining regulations. The raw correlations between the COORDINATE ONE measure and the subcategory estimate for factory regulations is 0.81 , while the correlation with the mining subcategory is -0.01 .

Meanwhile, the correlation of COORDINATE TWO with the mining regulations subcategory is 0.63 compared with -0.25 for its correlation with factory regulations. We can see these patterns in the maps in Figures 7 and 8. COORDINATE ONE has higher values primarily in manufacturing states in New England in the Midwest, while COORDINATE TWO has higher values mostly in states known for mining.

\section{Correlations Between the Measures}

Each of the measures can be considered to be summary measures in their own right, yet to some extent they measure different aspects of regulation as well. The relationships between the measures are shown in Tables 3 and 4. The cross-sectional correlations in Table 3 show the relationships in 1903, 1909, and again in 1919 between the stock of laws (level of spending), in essence, a snapshot of the entire body of state codes at a point in time. The same general patterns (with some minor exceptions) of correlation are present in all three years. In all three years relatively strong positive correlations above 0.61 can be found between the levels of the ESWI, the Page Counts, and the COORDINATE ONE measures. Labor Spending has positive but somewhat weaker correlations with those three measures; between 0.3 and 0.5 with the ESW Index, between 0.2 and 0.39 with the pages and 0.098 to 0.309 with the COORDINATE ONE. The COORDINATE TWO measure, which appears more focused 
on mining, has consistent correlations with labor spending per worker that ranges between 0.38 and 0.42 . It has positive and weaker correlations with the number of pages, 0.23 to 0.31 and with the ESWI, 0.12 to 0.22 , is also positively correlated.

The changes in the measures of the legal climate arise due to the new legislation enacted between time periods. Table 4 offers correlations across states for the change over the entire period from around 1900 to around 1919, and then separately for each of the two decades. The correlations of changes in the ESWI, labor spending per worker, COORDINATE ONE, and COORDINATE TWO for entire period from around 1900 to around 1919 range between .11 and .53 with the weakest correlation between COORDINATE ONE and labor spending per worker. Most of the strength of the correlations comes from the period 1909 to around 1919 because the correlations for that period are relatively close to those for the entire 1900 to 1919 period. The correlations from around 1900 to 1909 are much weaker.

\section{NATIONAL CHANGES}

The regulatory rise was a nation-wide phenomenon. In every scatter plot comparison of 1899 and 1919 nearly every state lies above the 45 degree line, which implies that the regulation measure has grown over time. Similarly, the maps for the regulatory measures all show a darkening over time for nearly every state. The national rise can also be seen when we aggregate the measures for the entire United States in Figure 10. We developed the national ESWI by weighting each of the state ESWI's in that year by that state's share of national employment in that year. ${ }^{25}$ The national labor spending per worker measure was developed by the labor spending measure and then dividing by the national total of mining and manufacturing workers. 
The national ESWI displays an 0.2 rise in the extent of regulation from 1900 through 1924 from a weighted index of 0.31 in 1899 to over 0.51 in 1924 . There was a relatively sharp rise between 1899 and 1903 and then the trend was relatively flat with a dip in 1908. Between 1908 and 1914 there was a substantial rise in the index from about .35 to about .47 that coincided with the introduction of many employer liability and workers' compensation laws. The trend stayed relatively flat through the end of World War I, followed by a rise to around 0.51 in the aftermath of the War.

Meanwhile labor spending per mining and manufacturing worker in 1967 dollars rose by roughly 8 cents between 1903 and 1905, stayed flat for several years, and then spiked by nearly 10 cents in 1908. The spending stayed flat another two years and then rose by nearly 60 cents between 1910 and 1915 with the wave of increased resources for inspection, the introduction of commissions to operate workers' compensation, and the expansion in a few states into Industrial Commissions that had their own rule-making authority. We have not yet collected information for all states for the period 1917 through 1920, but the information for the states for which we have collected data suggests that labor spending per worker in 1967 dollars declined. Increases in nominal labor spending were more than outpaced by the doubling of the consumer prices during that time period.

\section{CORRELATES OF THE LABOR REGULATORY CLIMATE}

The overall labor regulatory climate was the result of an accumulation of a broad range of policy choices in each state. The adoption of each labor law was the result of a series of proposals, counter proposals, negotiations, and compromises between the specific interest groups interested in those laws, the legislators, the governor, and voters, directly when the 
legislation was voted on in a referendum or indirectly through their representatives. At the same time many of the stances chosen on specific forms of regulation were part of broader agendas for the major interest groups, employers, unions, nonunion workers, and political parties. Our goal in this section is to show the fundamental correlations between the labor climate and politics and economic interest groups. We do this in two ways. First, we examine cross-sectional correlations that show the long run relationships between these factors and the stock of laws circa 1903/1904 near the beginning of the period of measurement and again in 1919. Second we examine the factors that influenced the changes in those laws in the first two decades of the twentieth century.

Table 5 shows the relationship between various measures of the stock of regulation and a series of political party and economic variables commonly seen as correlates of measures of labor legislation in 1904 and in $1919 .{ }^{26}$ We have tried a variety of cross-sectional analyses using different time periods, and the results are not dramatically different from those reported here.

The political party variables are the percentage of the population voting in presidential elections for the Republican presidential candidate, voting for the Socialist candidate, and voting for the 1912 Progressive Party candidate. We focus more on presidential voting because the stances taken by the candidates were on nationwide platforms and thus broadly consistent from state to state. The Democratic and Republican parties' positions in state politics often varied to some degree across states, particularly when comparing southern Democrats to Democrats in the rest of the country. Generally, Democrats outside the South, Progressives, and Socialists have been considered to have been more in tune with the interest of unions and workers than were Republicans, so we have incorporated a Democratic governor 
variable. Since nearly all southern Governors were Democrats, the South region dummy variable that we included and discuss later serves partly as an interaction term between the South and Democratic Governor.

We have also incorporated a series of variables that are broadly descriptive of the clout of major interest groups. An index of unionization shows the extent to which workers in the state are employed in industries where unions had a stronger nationwide presence. The size of the labor force and the percentages working in mining, manufacturing, and agriculture give a sense of the industrial structure of the states. Generally, agricultural states were expected to be more likely to be opposed to labor regulation, even though agricultural workers were typically exempted from the rules. There was a fear that the rules might be extended to agriculture in the future and that better workplaces would make it harder to keep workers from leaving agriculture for industrial jobs. The relative importance of large and small firms in manufacturing are measured by the percentage of manufacturing establishments with fewer than 20 workers and the percentage with more than 500 workers. We include the percentage foreign-born, black, and illiterate to examine the extent to which their relative lack of political clout and antipathy toward their presence influenced the labor regulation climate. Finally, to examine whether the southern legacy of slavery had additional impact on the choice of labor regulation above and beyond the political and economic factors we have incorporated a dummy variable for the Southern states that had been members of the Confederacy. ${ }^{27}$

The results from Ordinary Least Squares (OLS) regressions summarized in Tables 5 and 6 show the relationship of each of the major variables with the stock of the laws and level of labor spending per worker at the turn of the $20^{\text {th }}$ century and just after World War I, holding the other correlates constant. The Tables report one-standard-deviation (OSD) relationships 
that show how many standard deviations the labor regulation measure changes in response to a one-standard-deviation increase in the correlate. The t-statistic for the coefficient estimate is reported below each OSD measure. In the case of dummy variables we report the coefficient. To avoid simultaneity between the correlates and labor regulation measure in the same year, the values for the correlates with the labor climate in 1904 are from the years 1900 and 1899 and the values for correlates for the later year are from the period around 1910 and 1912 . We have also run the analysis with just the political variables and just the economic variables, and the basic results reported here for each of the factors are similar to the findings in those analyses.

The overall size of the gainfully employed has a positive effect on both the ESWI and the labor spending measure that strengthened over time. An increase of one standard deviation in the size of the labor force was associated with an increase of 0.166 standard deviations in the ESWI in 1904 and 0.324 standard deviations in 1919. The OSD relationships for the labor spending measure were 0.277 in 1904 and 0.286 in 1916 . The positive relationship between the labor force and regulation might arise because of the presence of substantial fixed costs of setting up and maintaining a regulatory regime. Regulations that have large public good effects are more likely to be established because so many more workers benefit relative to the costs of establishing the regulation. ${ }^{28}$

A higher share of gainfully employed in agriculture was associated with substantially less regulation as measured by the ESWI but displayed virtually no relationship with the labor spending measure. ${ }^{29}$ An OSD rise in the percent of the gainfully employed in agriculture was associated with a -0.731 standard deviation reduction in the ESWI in 1904 and a -0.791 reduction in 1919. Only the second relationship is estimated precisely enough that it is 
statistically significant in a two-tailed test at the 10 percent level. ${ }^{30}$ The farmers' antipathy toward regulation was shown not only by their success in ensuring that labor regulations were not applied to farming in many cases, but also the reduced degree of labor regulation in farm states. Once the regulations were established, however, the farmers did not appear to display much opposition to labor spending per worker in the nonagricultural fields. The OSD relationships with labor spending were both positive and imprecisely estimated.

In contrast, the share of workers in mining had a positive relationship with labor spending per mining and manufacturing worker. The dangers of the mines contributed to more extensive safety regulations in mines and a larger ratio of inspectors to workers in mining and in manufacturing. The OSD relationship was 0.916 for 1904 and 0.43 in 1919, although the latter was imprecisely estimated, and the hypothesis of no effect can not be rejected at the 10percent level.

A number of scholars have suggested that large firms often contributed to the adoption of labor regulation, while workers and unions had a more mixed attitude toward regulation, particularly before 1910, because they feared that employers had enough clout in state legislatures to control the regulations. ${ }^{31}$ The results here appear consistent with this description for the period around 1904, less so for 1919. If unions favored regulation, we would expect to see strong positive relationships between the regulation measures and the union index. ${ }^{32}$ The OSD relationships in states with a larger share of workers in industries with strong national unions are relatively small and positive in 1904 relative to most other effects in 1904, and they are not statistically significant. Large firms in manufacturing, on the other hand, displayed a strong positive relationship with regulation. The OSD relationships of the share of establishments with more than 500 workers were 0.549 and 0.705 , respectively. 
Given the controls for unionization and large manufacturing firms, the share of gainfully employed workers in manufacturing might be considered a measure of the political clout of either nonunion workers as voters or the overall weight of manufacturing employers and workers in the state. The share of manufacturing workers has very strong negative OSD relationships with the measures of labor regulation in 1904. A one standard deviation increase in the percent of workers in manufacturing was associated with an ESWI that was -0.873 standard deviations lower and a labor spending measure that was -0.557 lower, although only the former relationship is precisely estimated. The combination of findings for unions, large employers, and manufacturing suggest an important role for large manufacturing employers as early progenitors of regulation. By 1919, however, the relationships had weakened considerably in magnitude and were no longer precisely estimated.

The political party, Democratic governor, and the South dummy generally do not show consistently strong relationships with the stock of labor legislation at the two points in time. None of the political coefficients were precisely estimated and we cannot reject the hypothesis of no effect in two-tailed tests at the 10-percent level. States with more voting for Socialist presidential candidates were more likely to have more regulation and more labor spending with OSD relationships of 0.166 and 0.272 in 1904, and similar effects in later years. Progressive presidential votes in 1912 were slightly negatively associated with labor regulation. Meanwhile, Republican voting states had fewer laws but greater spending per worker in both years. These results fit with findings that Taft, Wilson, and Roosevelt all included a number of progressive planks related to labor in their political agendas.

States with Democratic governors show no strong association one way or the other with the state labor climates. The largest OSD relationships for the Democratic Governors were 
negative for the ESWI in 1904 and higher for the labor spending measure in 1919. Southern states in both periods were more likely to have lower labor spending per mining and manufacturing worker with OSD relationships of -0.654 . They appeared to have similar levels of the ESWI in 1904 but -0.309 standard deviation lower levels in 1919. Thus, after controlling for other economic features, the southern legacy appears to be more laws and less labor spending per worker in 1904, and less of both in 1919. Although here again, the coefficients are all imprecisely estimated.

Since the stock of legislation was the accumulation of a large number of laws that may have been passed between one to thirty years earlier, we also examine the relationships between the correlates and the change in labor legislation within the decade. Table 6 shows the OSD effects from regressions with two observations for nearly every state, the change in labor legislation or labor spending per worker in the first decade of the 1900s and the changes in the second decade. The correlates are measures of the situation at the beginning of each decade in most cases. The exceptions are measures of the number of changes in the political party of the governor and the party in power in the houses of the state legislature during the decade. These were included because studies by Fishback and Kantor (2000) and Pavalko (1989) both found effects of party power shifts on the adoption of workers' compensation.

Estimates are reported for regressions with and without fixed effects for the states and the timing. The state fixed effects are dummy variables for all states except Connecticut that are used to control for unmeasured factors that do not change over time within the same state but vary across states over time. These would include long-term political and economic features of the state that are unchanging over time, as well as the physical terrain of the state. The Second Decade year effect is a dummy variable for the observations on changes in labor 
regulation for the second decade of the 1900s. The dummy acts as a control for unmeasured nationwide factors that affected all states, including World War I or a national recession. The OSD effects in the estimations incorporating fixed effects are similar to estimating the average difference-in-difference relationship across states. In essence, we are seeing, on average, how differences in the correlates within the states influence differences in the changes in the state labor climate.

The main result that comes out of the analysis is the finding that the changes in the labor measure have a strong negative relationship with the prior stock of labor legislation or the prior level of labor spending. States with ESWI laws at the beginning of the period that are one standard deviation higher, experience changes in labor legislation that is -0.634 standard deviations lower in the absence of fixed effects and $\quad-1.953$ standard deviations lower when fixed effects are incorporated. The OSD effects are smaller for the labor spending per worker at -0.298 without fixed effects and -0.762 with fixed effects. The results suggest that there tend to be a reasonably strong catch-up effects in labor legislation. Other states eventually join the early adopting states in adopting many forms of labor legislation. In the fixed effects analysis, states with a larger share of large firms are more likely to adopt new legislation although not necessarily to increase spending per worker.

Most of the strong effects found when fixed effects are not incorporated in the analysis are weakened or reversed with the inclusion of fixed effects. This includes the positive relationships for the share of the population voting Socialist for president for both labor measures. For labor spending per worker, the positive relationships are reversed for the mining share and the agricultural share, the percent foreign-born, and diminished sharply for the number of changes in the party in charge of the lower house of the legislature. 
In the fixed effects analysis there were sizeable OSD relationships between the labor measures and the number of gainfully employed workers and the percent black (OSDs over 1 for both). Large firms had a strong positive OSD relationship with the ESWI at 0.81 , as did Democratic Governors at 0.676. Collective action had mixed effects. Increased strike activity during the decade was associated with over 0.6 OSD relationships with both measures. Meanwhile, the unionization index showed both a positive relationship with the ESWI and a negative relationship with the spending measures. In all of these cases, some care must be exercised in drawing conclusions due to the imprecision of the estimation shown by the low absolute values of the t-statistics.

The fixed effects show the effects of unmeasured factors related to the states that influenced the choice of labor legislation. The states that ranked in the top 10 in unmeasured factors that were positively related to larger increases in the ESWI, include, in order from the top, the western and Midwestern states of Colorado, Montana, Nevada, Idaho, Utah, Minnesota, Michigan, Wisconsin, Kansas, and Iowa. The bottom ten were generally in the South and the Mid-Atlantic, including from bottom South Carolina, Mississippi, Florida, Georgia, Alabama, Louisiana, Virginia, North Carolina, Texas, and New York.

The states that ranked in the top 10 in unmeasured factors that were positively related to larger increases in labor regulation spending per worker, include, in order from the top, the mostly western states of North Dakota, Idaho, South Dakota, Nevada, Montana, New Mexico, Arizona, West Virginia, Minnesota, and Colorado. The bottom ten were again generally in the South and the Mid-Atlantic, including from bottom Mississippi, South Carolina, Georgia, Louisiana, Florida, Alabama, Virginia,New York, North Carolina, and Maryland. 
Note that these estimates are effects estimated after controlling for the size of the labor force, the shares of mining, agriculture, firm sizes, industrial mix related to unionization, and many political factors. The results for the changes in laws thus suggest a stronger negative role for the unmeasured Southern Legacy than the results for the stock of laws. The results also leave a great deal of room for the important type of institutional analysis traditionally performed in narrative labor and business histories.

\section{CONCLUSIONS}

The regulatory climate in the labor arena during the progressive era was marked by both great breadth and complexity. In the search for understanding about the interrelationships between labor markets, politics, and labor regulation we need both summary measures as well as studies in-depth of the institutions. The summary measures allow people to make broad comparisons of the overall labor regulation across states and how these changed over time. There is no doubt that they can be improved by going into more depth on each type of regulation. Suggestions for improvement, particularly when accompanied by new information that will improve the measures, are welcome.

Further, we can use the measures to perform rudimentary statistical analysis of the interactions of these factors. The brief analysis of the correlates of the stock of labor regulation and the changes in labor regulation show several important relationships that appear after holding other factors constant. The extent of labor regulation was related to the overall size of the labor force. States with larger establishments tended to have more regulation early on and were more likely to adopt changes in labor legislation. States with industries with a strong national union presence do not seem to be associated positively or negatively with the 
regulatory climate. States that lagged behind the early adopters tended to eventually catch-up and adopt many forms of labor regulation. Finally, southern states were typically at the bottom of the list in terms of making changes in their regulations.

The results of the analysis also show that the statistical studies can only carry us part of the way toward understanding the development of labor regulation. Hidden in the fixed effects in the statistical analysis are many factors in the states that are not necessarily easily measured quantitatively. Careful analysis of both statistical and narrative evidence is important for understanding the relationships between labor regulations and the society. Our hope is that scholars of all types find these summary measures useful for comparative purposes in their own work. 
Table 1

Years of Introduction of Labor Commission, Factory Inspectors, Departments of Labor, Industrial Commissions, Workers' Compensation and Coal Mine Safety Laws

\begin{tabular}{|c|c|c|c|c|c|c|}
\hline State & $\begin{array}{c}\text { First } \\
\text { Labor } \\
\text { Bureau }\end{array}$ & $\begin{array}{l}\text { Factory } \\
\text { Inspection } \\
\text { Adopted }\end{array}$ & $\begin{array}{l}\text { Industrial } \\
\text { Commission } \\
\text { Introduced }\end{array}$ & $\begin{array}{c}\text { Extent of } \\
\text { Code- } \\
\text { Writing } \\
\text { by Ind. } \\
\text { Comm. }\end{array}$ & $\begin{array}{c}\text { Permanent } \\
\text { Workers' } \\
\text { Compensation } \\
\text { Law }\end{array}$ & $\begin{array}{c}\text { Coal } \\
\text { Mining } \\
\text { Safety } \\
\text { Law } \\
\text { Adopted }\end{array}$ \\
\hline Alabama & $1907^{\mathrm{a}}$ & $1907^{\mathrm{a}}$ & & & 1919 & 1891 \\
\hline Arizona & $1925^{b}$ & $\mathrm{~b}$ & 1925 & Few & 1913 & no coal \\
\hline Arkansas & 1913 & c & & & 1939 & 1889 \\
\hline California & 1883 & 1885 & 1913 & extensive & 1911 & no coal \\
\hline Colorado & 1887 & 1911 & 1915 & no codes & 1915 & 1883 \\
\hline Connecticut & 1887 & 1887 & & & 1913 & no coal \\
\hline Delaware & 1893 & 1893 & & & 1917 & no coal \\
\hline Florida & $1893^{\mathrm{d}}$ & e & & & 1935 & no coal \\
\hline Georgia & 1911 & 1916 & & & 1920 & no coal \\
\hline Idaho & $1890^{\mathrm{f}}$ & $\mathrm{g}$ & 1917 & no codes & 1917 & no coal \\
\hline Illinois & 1879 & 1893 & & & 1911 & 1872 \\
\hline Indiana & 1879 & 1899 & & & 1915 & 1879 \\
\hline Iowa & 1884 & 1897 & & & 1913 & 1873 \\
\hline Kansas & 1885 & 1901 & & & 1911 & 1883 \\
\hline Kentucky & $1892^{\mathrm{h}}$ & 1903 & & & 1914 & 1884 \\
\hline Louisiana & 1900 & 1908 & & & 1914 & no coal \\
\hline Maine & 1887 & 1887 & & & 1915 & no coal \\
\hline Maryland & $1888^{\mathrm{i}}$ & 1898 & 1928 & no codes & 1912 & 1876 \\
\hline Massachusetts & 1869 & 1879 & 1913 & extensive & 1911 & no coal \\
\hline Michigan & 1883 & 1893 & & & 1912 & 1887 \\
\hline Minnesota & $1887^{\mathrm{j}}$ & 1891 & & & 1913 & no coal \\
\hline Mississippi & 1914 & 1914 & & & 1948 & no coal \\
\hline Missouri & 1879 & $1891^{\mathrm{k}}$ & & & 1926 & 1881 \\
\hline Montana & $1893^{1}$ & $1 \mathrm{~m}$ & 1915 & no codes & 1915 & 1889 \\
\hline Nebraska & $1887^{\mathrm{n}}$ & $1895^{n}$ & 1929 & no codes & 1913 & no coal \\
\hline Nevada & 1915 & 1915 & 1919 & Few & 1913 & no coal \\
\hline $\begin{array}{l}\text { New } \\
\text { Hampshire }\end{array}$ & 1893 & 1917 & 1917 & no codes & 1911 & no coal \\
\hline New Jersey & 1877 & 1878 & & & 1911 & no coal \\
\hline New Mexico & o & o & & & 1917 & 1891 \\
\hline New York & 1882 & 1883 & 1913 & extensive & 1913 & no coal \\
\hline
\end{tabular}




\begin{tabular}{|c|c|c|c|c|c|c|}
\hline $\begin{array}{l}\text { North } \\
\text { Carolina }\end{array}$ & 1887 & $\mathrm{e}$ & 1931 & & 1929 & no coal \\
\hline North Dakota & 1899 & 1905 & 1919 & no codes & 1919 & 1905 \\
\hline Ohio & 1877 & 1884 & 1913 & extensive & 1911 & 1874 \\
\hline Oklahoma & 1907 & 1910 & & & 1915 & 1891 \\
\hline Oregon & 1903 & 1907 & 1920 & few & 1913 & no coal \\
\hline Pennsylvania & 1872 & 1889 & $\begin{array}{l}1913 \text { for } \\
\text { mines only }\end{array}$ & extensive & 1915 & $\begin{array}{c}1869 \\
\text { Anthracite; } \\
1877 \\
\text { Bituminous }\end{array}$ \\
\hline Rhode Island & 1887 & 1894 & & & 1912 & no coal \\
\hline $\begin{array}{l}\text { South } \\
\text { Carolina }\end{array}$ & 1912 & 1912 & & & 1935 & no coal \\
\hline South Dakota & 1890 & $\mathrm{p}$ & & & 1917 & no coal \\
\hline Tennessee & $\underset{\mathrm{q}}{1881-84}$ & $1897^{\mathrm{r}}$ & 1923 & few & 1919 & 1881 \\
\hline Texas & 1911 & 1911 & & & 1913 & 1907 \\
\hline Utah & $1892^{\mathrm{s}}$ & 1917 & 1917 & extensive & 1917 & 1896 \\
\hline Vermont & 1912 & 1912 & & & 1915 & no coal \\
\hline Virginia & 1897 & 1919 & & & 1918 & 1912 \\
\hline Washington & 1903 & 1910 & 1919 & few & 1911 & 1883 \\
\hline West Virginia & $1890^{t}$ & $1899^{r}$ & & & 1913 & 1883 \\
\hline Wisconsin & 1883 & 1883 & 1911 & extensive & 1911 & no coal \\
\hline Wyoming & 1917 & 1917 & & & 1915 & 1886 \\
\hline
\end{tabular}

Sources: First Labor Bureau refers to the introduction of either a commissioner of labor, a bureau of labor statistics, or a factory inspector. Factory inspection adopted refers to the first statutory provision for a factory inspector. For dates of adoption of inspectors and departments of labor I started with evidence from Brandeis (1935, pp. 628-645) and the U.S. Commissioner of Labor (1896). When the precise date of introduction was unknown, the microfiche for the State Session Laws of American States and Territories was searched until the original act was found. The earliest commissioner of labor was in Massachusetts in 1869 and the earliest factory inspector was in Massachusetts in 1879.

Information on workers and establishments for 1880 is from the Report on Manufacturing for the Eleventh Census (U.S. Census Bureau, 1895, pp. 67-69). Information on Industrial Commissions is from Brandeis (1935, p. 654), who was citing work of John Andrews of the American Association of Labor Legislation. The information on the adoption of workers' compensation is from Fishback and Kantor (2000, pp. 103-4). Information that was not available is marked as n.a. Year of coal law adoption is from Aldrich (1997, p. 70).

aAlabama had a mine inspector and later a board of arbitration but no official department of labor.

${ }^{\mathrm{b}}$ Arizona had a mine inspector as of 1908 .

${ }^{c}$ Arkansas had an inspector of mines in 1894 or earlier.

${ }^{\mathrm{d}}$ The Florida Agriculture department was given the responsibility to collect statistics on manufactures.

${ }^{\mathrm{e}}$ No law as of 1924. 
${ }^{\mathrm{f}}$ Idaho established commission in Constitution. No record of laws passed between 1879 and 1890.

${ }^{g}$ Idaho had an inspector of mines in 1893 or earlier.

${ }^{\mathrm{h}}$ The Kentucky commissioner was to devote efforts to collect statistics on agriculture, manufacturing and mining.

${ }^{\mathrm{i}}$ The initial Maryland law in 1868 was for agriculture and industry with most of the focus on agriculture. The code of 1888 with amendments in 1892 is more specific to industry.

${ }^{\mathrm{j}}$ The Minnesota law included language about enforcing laws and prosecuting violations by the commissioner but only funds for the commissioner were provided.

${ }^{\mathrm{k}}$ Missouri statute for inspector in 1891. Not found in earlier years.

${ }^{1}$ The Montana act established a bureau of agriculture, labor, and industry.

${ }^{\mathrm{m}}$ Montana had a mine inspector in 1895 or earlier.

${ }^{\mathrm{n}}$ Nebraska gave the commissioner the power to inspect workplaces.

${ }^{\circ}$ New Mexico had a mine inspector as of 1908.

${ }^{\mathrm{p}}$ South Dakota had a mine inspector as of 1903.

${ }^{\mathrm{q}}$ The Tennessee Law called for the Bureau of Agriculture, Mining, and Statistics to collect information on labor. The original Bureau of Agriculture was established in 1871, became the Bureau of Agriculture, Mining, and Statistics in 1875, but appears to have obtained the role of collecting labor statistics sometime between 1881 and 1884 . We have had trouble pinning down the date.

${ }^{r}$ In Tennessee and West Virginia there were no regular inspectors. Commissioner merely had the power to inspect.

${ }^{\mathrm{s}}$ The Utah legislature had authorized a bureau of labor statistics or labor department earlier.

${ }^{t}$ West Virginia gave the commissioner the power to inspect workplaces but only to report on findings there. 
Table 2

Correlations of Labor Measures Across Time

ESW Index 1899

ESW Index 1909

ESW ESW ESW

Index Index Index

$1899 \quad 1909 \quad 1919$

ESW Index 1919

Pages 1904

Pages 1907

Pages 1914

Labor Spending per Worker, 1903

Labor Spending per Worker 1909

Labor Spending per Worker 1916

COORD ONE 1899

$\begin{array}{ccc}\text { Pages } & \text { Pages } & \text { Pages } \\ 1904 & 1907 & 1914\end{array}$

0.8322

$\begin{array}{lll}0.7257 & 0.8618 & 1\end{array}$

1

$\begin{array}{ccc}0.9813 & 1 & \\ 0.9098 & 0.9339 & 1\end{array}$

Labor Labor Labor

Spending Spending Spending

per per per

Worker Worker Worker

$1903 \quad 1909 \quad 1916$

1

$0.7458 \quad 1$

$\begin{array}{lll}0.4953 & 0.7766 & 1\end{array}$

COORD COORD COORD

ONE ONE ONE

$1899 \quad 1909 \quad 1919$

COORD ONE 1909

COORD ONE 1919

$\begin{array}{ccc}0.8099 & 1 & \\ 0.76 & 0.7399 & 1\end{array}$

COORD COORD COORD

TWO TWO TWO

$1899 \quad 1909 \quad 1919$

COORD TWO 1899

1

COORD TWO 1909

$\begin{array}{ll}0.8503 & 1\end{array}$

COORD TWO 1919

$\begin{array}{lll}0.7227 & 0.8743 & 1\end{array}$


Table 3

Cross-Sectional Correlations of Labor Measures At Specific Points in Time

\begin{tabular}{ccccc} 
ESW & Pages & Labor & COORD & COORD \\
Index & 1904 & Spending & ONE & TWO \\
1899 & & per & 1899 & 1899 \\
& \multicolumn{5}{c}{ Worker } \\
& 1903 &
\end{tabular}

ESW Index 1899

1

Pages 1904

0.7277

Labor Spending per Mining and

0.4784

Manufacturing Worker 1903

COORD ONE 1899

0.8338

0.2193

0.7946

1

COORD TWO 1899

$\begin{array}{ccccc}\text { ESW } & \text { Pages } & \text { Labor } & \text { COORD } & \text { COORD } \\ \text { Index } & 1907 & \text { Spending } & \text { ONE } & \text { TWO } \\ 1909 & & \text { per } & 1909 & 1909 \\ & & \text { Worker } \\ & & & \end{array}$

ESW Index 1909

1

Pages 1907

0.6327

0.3112

0.3094

1

0.3831

0.1134

1

Labor Spending per Mining and

0.3537

Manufacturing Worker 1909

COORD ONE 1909

0.7684

0.1767

0.7297

0.0977

0.2322

0.3827

1

COORD TWO 1909

$\begin{array}{cccc}\text { ESW } & \text { Labor } & \text { COORD } & \text { COORD } \\ \text { Index } & \text { Spending } & \text { ONE } & \text { TWO } \\ 1919 & \text { per } & 1919 & 1919 \\ & \text { Worker } & & \\ & 1916 & & \end{array}$

ESW Index 1919

1

Labor Spending per Mining and

0.4907

Manufacturing Worker 1916

COORD ONE 1919

0.829

0.1235

0.2754

$0.4261 \quad-0.0335$

1 
Table 4

Cross-Sectional Correlations of Changes in Labor Measures

$\begin{array}{cccc}\text { ESW } & \text { Labor } & \text { COORD } & \text { COORD } \\ \text { Index } & \text { Spending } & \text { ONE } & \text { TWO } \\ 1919- & \text { per } & 1919- & 1919- \\ 1899 & \text { Worker } & 1899 & 1899 \\ & 1916- & & \\ & 1903 & & \end{array}$

ESW Index 1919-1899

1

Labor Spending per

$0.5309 \quad 1$

Manufacturing and Mining

Worker 1916-1903

COORD ONE 1919-1899

$\begin{array}{cccc}0.4622 & 0.1125 & 1 & \\ 0.3684 & 0.4319 & 0.3331 & 1 \\ & & & \\ \text { ESW } & \text { Labor } & \text { COORD } & \text { COORD } \\ \text { Index } & \text { Spending } & \text { ONE } & \text { TWO } \\ 1919- & \text { per } & 1919- & 1919- \\ 1909 & \text { Worker } & 1909 & 1909 \\ & 1916- & & \\ & 1909 & & \end{array}$

ESW Index 1919-1909

1

Labor Spending per

$0.2645 \quad 1$

Manufacturing and Mining

Worker 1916-1909

COORD ONE 1919-1909

$\begin{array}{cccc}0.5537 & 0.1125 & 1 & \\ 0.245 & 0.4319 & 0.3149 & 1 \\ & & & \\ \text { ESW } & \text { Labor } & \text { COORD } & \text { COORD } \\ \text { Index } & \text { Spending } & \text { ONE } & \text { TWO } \\ 1909- & \text { per } & 1909- & 1909- \\ 1899 & \text { Worker } & 1899 & 1899 \\ & 1909- & & \\ & 1903 & & \end{array}$

ESW Index 1909-1899

1

Labor Spending per

$0.2776 \quad 1$

Manufacturing and Mining

Worker 1909-1903

COORD ONE 1909-1899

$\begin{array}{lll}0.2368 & -0.0702 & 1\end{array}$

COORD TWO 1909-1899

$\begin{array}{lll}0.1188 & 0.3347 & -0.0363\end{array}$ 
Table 5

One Standard Deviation Effects of Correlates on Stock of Labor Legislation and Labor

Spending per Mining and Manufacturing Worker (1967\$)

(t-statistics of Coefficients in Italics Below OSD Effects)

(Standard Deviation of Correlate Below Mean)

Correlate

Unionization Index, 1899

$\%$ Voting Republican for

President, 1900

$\%$ Voting Socialist for

President, 1900

Number of Gainfully

Employed, 1900

$\%$ of Manu. Estabs. With

fewer than 20 workers,

1899

$\%$ of Manu. Estabs. With

More than 500 workers,

1899

\% black, 1900

$\%$ foreign born, 1900

$\%$ Illiterate, 1900

$\%$ of Gainfully Employed

in Agriculture, 1900

$\%$ of Gainfully Employed

in Mining, 1900

$\%$ of Gainfully Employed

in Manufacturing, 1900

Dummy Variables

Governor is a Democrat,

1900
Labor

Spending

per

ESWI, Worker,

$1904 \quad 1904$

0.124

0.75

$-0.388$

$-1.36$

0.166

1.03

0.131

0.76

0.267

0.64

0.272

1.33

0.264

2.19

$-0.060$

$-0.28$

0.549

1.94

$-0.606$

$-0.92$

$-0.300$

$-1.43$

$-0.216$

$-0.32$

$-0.731$

$-1.3$

0.131

0.66

$-0.873$

$-1.77$

$-0.298$

$-1$

0.105

0.277

1.68

0.087

0.36

0.705

2.14

0.387

0.48

0.040

0.19

$-0.546$

$-0.69$

0.429

0.57

0.916

3.11

$-0.557$

$-0.84$

0.014

0.03

$-0.654$
Mean

Std.

Dev.

6.5 Unionization Index,

2.91909

48.2 \% Voting Republican

14.2 for President, 1912

$0.5 \%$ Voting Socialist for

0.6 President, 1912

\% Voting Progressive

Party for President,

1912
559090 Number of Gainfully

$71.3 \%$ of Manu. Estabs.

With fewer than 20

6.5

0.4

workers, 1909

$\%$ of Manu. Estabs.

With More than 500

0.4

$11.2 \%$ black, 1910

17.4

$14.0 \%$ foreign born, 1910

10.2

11.9

10.8

39.4

18.9

2.8

4.51910

22.6

$\%$ of Gainfully

Employed in

11.7 Manufacturing, 1910

0.438

0.501

0.216
Governor is a

Democrat, 1912

Southern State
568534 Employed, 1910
Labor

Spending

per

Worker

$1919 \quad 1916$ Dev.

$\begin{array}{lll}-0.097 & -0.016 & 8.5\end{array}$

$\begin{array}{lll}-0.54 & -0.06 & 3.5\end{array}$

$\begin{array}{lll}-0.023 & 0.425 & 46.5\end{array}$

$\begin{array}{lll}-0.08 & 1.34 & 14.8\end{array}$

$\begin{array}{lll}0.128 & 0.337 & 6.0\end{array}$

$\begin{array}{rrr}0.54 & 1.22 & 4.2\end{array}$

$\begin{array}{lll}-0.070 & -0.170 & 24.5\end{array}$

$\begin{array}{rrr}-0.41 & -1.08 & 10.3\end{array}$

$\begin{array}{lll}0.324 & 0.286 & 716988\end{array}$

$2.4 \quad 701803$

$\begin{array}{lll}0.075 & -0.002 & 75.2\end{array}$

$\begin{array}{lll}0.28 & -0.01 & 5.5\end{array}$

$\begin{array}{lll}0.274 & 0.114 & 0.6\end{array}$

$\begin{array}{lll}0.98 & 0.47 & 0.5\end{array}$

$\begin{array}{lll}-0.179 & 0.512 & 10.6\end{array}$

$\begin{array}{lll}-0.57 & 1.75 & 16.4\end{array}$

$\begin{array}{lll}-0.001 & 0.214 & 14.0\end{array}$

$\begin{array}{lll}-0.01 & 0.98 & 10.1\end{array}$

$\begin{array}{lll}-0.219 & -0.322 & 8.4\end{array}$

$\begin{array}{lll}-0.83 & -1.42 & 7.3\end{array}$

$\begin{array}{lll}-0.791 & 0.057 & 37.3\end{array}$

$-1.77$

0.11

19.1

$-0.183$

0.430

3.4

$-0.84$

1.39

4.8

$-0.544$

$-0.278$

24.9

$-0.99$

$-0.56$

12.4

0.031

0.219

0.563

0.11

0.79

0.501

$-0.309$

$-0.640$ 


$\begin{array}{lrrrrrrr}\text { Southern State } & 0.14 & -1.13 & 0.415 & & -0.77 & -1.2 & 0.415 \\ \text { Constant } & 7.064 & -2.092 & & \text { Constant } & 4.370 & -0.675 & \\ & 2.76 & -0.65 & & & 0.89 & -0.13 \\ \text { Rsquared } & 0.676 & 0.593 & & & 0.625 & 0.672\end{array}$

Notes. The One-Standard Deviation (OSD) Effects for continuous variables show the number of standard deviations by which the dependent variable changes with respect to a one-standarddeviation increase in the variable. The OSD Effects for dummy variables show the number of standard deviations by which the dependent variable changes with respect to a move from zero to one of the dummy variable. Robust t-statistics are presented in italics below the OSD Effects. Means with Standard Deviations are reported for each of the Correlates to the right of the OSD Effects and the t-statistics.

The dependent variables are the ESWI in 1904 and 1919 and Labor Spending (in \$1967) per mining and manufacturing worker in 1904 and 1916. For the ESWI in 1904 the mean is 0.24 and the standard deviation is 0.125 , for the labor spending measure in 1904 the mean is 0.42 and standard deviation is 0.36 . For the ESWI in 1919 the mean is 0.35 and the standard deviation is 0.14 , for the labor spending measure in 1916 the mean is 0.92 and standard deviation is 0.77 .

There are observations for all 48 states in the 1916 and 1919 regressions. Arizona, New Mexico, and Oklahoma are missing from the 1904 regressions due to lack of presidential voting information in 1900. The data sources are described in Fishback and Kantor (2000) and the data on all correlates were pulled from the workers' compensation data sets on Price Fishback's website at the University of Arizona Department of Economics: http://economics.eller.arizona.edu/faculty/Fishback.aspx. 
Table 6

One Standard Deviation Effects of Correlates on Changes in Labor Legislation and Changes in Labor Spending per Mining and Manufacturing Worker (t-statistics of Coefficients in Italics Below)

\begin{tabular}{|c|c|c|c|c|c|c|}
\hline & \multicolumn{2}{|c|}{$\begin{array}{c}\text { ESWI at End of } \\
\text { Decade }\end{array}$} & \multicolumn{2}{|c|}{$\begin{array}{l}\text { Labor Spending } \\
\text { per Mining and } \\
\text { Manufacturing } \\
\text { Worker at End of } \\
\text { Decade (1967\$) }\end{array}$} & \multirow[b]{2}{*}{ Mean } & \multirow[b]{2}{*}{$\begin{array}{l}\text { Std. } \\
\text { Dev. }\end{array}$} \\
\hline & $\begin{array}{l}\text { No } \\
\text { Fixed } \\
\text { Effects }\end{array}$ & $\begin{array}{l}\text { Fixed } \\
\text { Effects }\end{array}$ & $\begin{array}{l}\text { No } \\
\text { Fixed } \\
\text { Effects }\end{array}$ & $\begin{array}{l}\text { Fixed } \\
\text { Effects }\end{array}$ & & \\
\hline ESWI at Beginning of Decade & $\begin{array}{r}-0.634 \\
-3.05\end{array}$ & $\begin{array}{r}-1.953 \\
-4.71\end{array}$ & & & 0.23 & 0.13 \\
\hline $\begin{array}{l}\text { Labor Spending per Mining and } \\
\text { Manufacturing Worker (\$1967) } \\
\text { at Start of Decade }\end{array}$ & & & $\begin{array}{r}-0.298 \\
-2.45\end{array}$ & $\begin{array}{r}-0.762 \\
-1.76\end{array}$ & 0.51 & 0.47 \\
\hline $\begin{array}{l}\% \text { Voting Republican for } \\
\text { President }\end{array}$ & $\begin{array}{r}-0.239 \\
-0.99\end{array}$ & $\begin{array}{r}-0.757 \\
-1.34\end{array}$ & $\begin{array}{r}0.091 \\
0.46\end{array}$ & $\begin{array}{r}0.294 \\
0.37\end{array}$ & 47.3 & 14.4 \\
\hline$\%$ Voting Socialist for President & $\begin{array}{r}0.206 \\
1.33\end{array}$ & $\begin{array}{r}-0.137 \\
-0.36\end{array}$ & $\begin{array}{r}0.339 \\
2.18\end{array}$ & $\begin{array}{r}-0.196 \\
-0.49\end{array}$ & 3.3 & 4.1 \\
\hline $\begin{array}{l}\% \text { Voting Progressive for } \\
\text { President }\end{array}$ & $\begin{array}{r}0.000 \\
0.42\end{array}$ & $\begin{array}{r}0.000 \\
0.23\end{array}$ & $\begin{array}{r}0.000 \\
-0.36\end{array}$ & $\begin{array}{r}0.000 \\
-1.06\end{array}$ & 11.9 & 14.2 \\
\hline $\begin{array}{l}\text { Number of Gainfully Employed } \\
\text { Workers }\end{array}$ & $\begin{array}{r}0.148 \\
0.47\end{array}$ & $\begin{array}{r}1.067 \\
1.02\end{array}$ & $\begin{array}{r}0.037 \\
0.14\end{array}$ & $\begin{array}{r}1.353 \\
1.15\end{array}$ & 638039 & 640222 \\
\hline $\begin{array}{l}\% \text { of Manu. Estabs with fewer } \\
\text { than } 20 \text { workers }\end{array}$ & $\begin{array}{r}0.152 \\
0.95\end{array}$ & $\begin{array}{r}-0.037 \\
-0.13\end{array}$ & $\begin{array}{r}-0.145 \\
-1.05\end{array}$ & $\begin{array}{r}0.039 \\
0.14\end{array}$ & 73.3 & 6.3 \\
\hline$\%$ of Manu. Estabs with More & 0.160 & 0.813 & -0.187 & -0.521 & 0.5 & 0.5 \\
\hline & 0.69 & 1.29 & -0.83 & -0.85 & & \\
\hline $\begin{array}{l}\% \text { of Gainfully Employed in } \\
\text { Agriculture }\end{array}$ & $\begin{array}{r}-0.427 \\
-0.98\end{array}$ & $\begin{array}{r}-1.490 \\
-0.72\end{array}$ & $\begin{array}{r}0.689 \\
1.89\end{array}$ & $\begin{array}{r}-2.920 \\
-1.24\end{array}$ & 38.3 & 18.9 \\
\hline $\begin{array}{l}\% \text { of Gainfully Employed in } \\
\text { Mining }\end{array}$ & -0.067 & -0.692 & 0.509 & -0.286 & 3.1 & 4.6 \\
\hline & -0.46 & -1.41 & 3.36 & -0.39 & & \\
\hline$\%$ of Gainfully Employed in & -0.204 & -0.415 & 0.363 & -1.127 & 23.7 & 12.1 \\
\hline & -0.42 & -0.47 & 1.06 & -0.8 & & \\
\hline Unionization Index & $\begin{array}{r}-0.097 \\
-0.59\end{array}$ & $\begin{array}{r}0.231 \\
0.85\end{array}$ & $\begin{array}{r}-0.038 \\
-0.23\end{array}$ & $\begin{array}{r}-0.336 \\
-0.77\end{array}$ & 7.5 & 3.4 \\
\hline$\%$ Black & $\begin{array}{r}-0.364 \\
-1.26\end{array}$ & $\begin{array}{r}3.570 \\
0.78\end{array}$ & $\begin{array}{r}0.143 \\
0.56\end{array}$ & $\begin{array}{r}5.997 \\
1.22\end{array}$ & 10.9 & 16.8 \\
\hline$\%$ Foreign-Born & $\begin{array}{r}0.009 \\
0.07\end{array}$ & $\begin{array}{r}0.057 \\
0.05\end{array}$ & $\begin{array}{r}0.389 \\
2.01\end{array}$ & $\begin{array}{r}0.178 \\
0.16\end{array}$ & 14.0 & 10.1 \\
\hline & 0.107 & 0.673 & 0.242 & 0.624 & 62.5 & 111.5 \\
\hline
\end{tabular}


Average Number of Strikes in

Decade

Governor is Democrat at start of decade

Number of Changes of Party of

Governor in Decade

Number of Changes in Party

Control of Upper House of

Legislature in Decade

Number of Changes in Party

Control of Lower House of

Legislature in Decade

Southern State

Second Decade Dummy

Constant

R-Squared

State Effects

ME

MA

$\mathrm{NH}$

RI

VT

DE

NJ

NY

PA

IL

IN

MI

$\begin{array}{rrrrrr}0.35 & 0.45 & 0.79 & 0.46 & & \\ & & & & & \\ 0.211 & 0.676 & -0.091 & 0.003 & 0.427 & 0.497 \\ 0.83 & 1.38 & -0.3 & 0 & & \\ -0.046 & 0.062 & 0.010 & -0.211 & 1.354 & 1.046 \\ & & & & & \\ -0.46 & 0.27 & 0.1 & -0.86 & & \\ 0.047 & -0.270 & -0.024 & -0.063 & 0.740 & 1.215 \\ 0.32 & -0.86 & -0.23 & -0.36 & & \\ & & & & & \\ -0.014 & -0.111 & 0.296 & 0.301 & 0.834 & 1.382 \\ -0.17 & -0.47 & 2.87 & 1.35 & & \\ & & & & & \\ -0.626 & & -0.078 & & 0.216 & 0.413 \\ -1.23 & & -0.17 & & & \end{array}$

0.783

0.42

$\begin{array}{rrrr}2.472 & 6.652 & -1.104 & 5.684 \\ 0.89 & 0.71 & -0.56 & 0.56\end{array}$

$\begin{array}{llll}0.89 & 0.71 & -0.56 & 0.56\end{array}$

$\begin{array}{llll}0.31 & 0.5 & 0.34 & 0.87\end{array}$

Included

3.103

1.24

$-0.580$

$-0.23$

2.296

1.29

Included

0.762

0.31

$-1.915$

$-0.88$

1.349

0.95

0.241

0.24

1.373

0.44

$-5.148$

$-0.82$

$-3.583$

$-1.78$

$-9.873$

$-1.37$

$-5.088$

$-1.07$

$-3.754$

$-1.17$

0.003

3.238

0

$-0.230$ 


\begin{tabular}{|c|c|c|}
\hline $\mathrm{OH}$ & $\begin{array}{r}0.650 \\
0.16\end{array}$ & $\begin{array}{r}-1.396 \\
-0.4\end{array}$ \\
\hline WI & $\begin{array}{r}3.924 \\
1.52\end{array}$ & $\begin{array}{r}1.048 \\
0.43\end{array}$ \\
\hline IO & $\begin{array}{r}3.433 \\
0.91\end{array}$ & $\begin{array}{r}0.939 \\
0.25\end{array}$ \\
\hline $\mathrm{KS}$ & $\begin{array}{r}3.519 \\
0.91\end{array}$ & $\begin{array}{r}1.652 \\
0.38\end{array}$ \\
\hline $\mathrm{MN}$ & $\begin{array}{r}4.349 \\
1.68\end{array}$ & $\begin{array}{r}2.961 \\
1.11\end{array}$ \\
\hline $\mathrm{MO}$ & $\begin{array}{r}0.252 \\
0.06\end{array}$ & $\begin{array}{r}-2.047 \\
-0.49\end{array}$ \\
\hline $\mathrm{NE}$ & $\begin{array}{r}2.528 \\
0.84\end{array}$ & $\begin{array}{r}2.307 \\
0.61\end{array}$ \\
\hline ND & $\begin{array}{r}3.069 \\
0.74\end{array}$ & $\begin{array}{r}6.729 \\
1.56\end{array}$ \\
\hline SD & $\begin{array}{r}1.585 \\
0.4\end{array}$ & $\begin{array}{r}4.943 \\
1.16\end{array}$ \\
\hline VA & $\begin{array}{r}-7.782 \\
-0.8\end{array}$ & $\begin{array}{r}-10.638 \\
-0.89\end{array}$ \\
\hline AL & $\begin{array}{r}-10.343 \\
-0.84\end{array}$ & $\begin{array}{r}-11.402 \\
-0.72\end{array}$ \\
\hline $\mathrm{AR}$ & $\begin{array}{r}-4.476 \\
-0.5\end{array}$ & $\begin{array}{r}-5.942 \\
-0.51\end{array}$ \\
\hline FL & $\begin{array}{r}-11.287 \\
-0.91\end{array}$ & $\begin{array}{r}-12.933 \\
-0.92\end{array}$ \\
\hline GA & $\begin{array}{r}-10.885 \\
-0.84\end{array}$ & $\begin{array}{r}-14.059 \\
-0.87\end{array}$ \\
\hline LA & $\begin{array}{r}-8.564 \\
-0.68\end{array}$ & $\begin{array}{r}-13.907 \\
-0.89\end{array}$ \\
\hline $\mathrm{MS}$ & $\begin{array}{r}-13.167 \\
-0.81\end{array}$ & $\begin{array}{r}-16.015 \\
-0.79\end{array}$ \\
\hline $\mathrm{NC}$ & $\begin{array}{r}-5.788 \\
-0.61\end{array}$ & $\begin{array}{r}-8.227 \\
-0.68\end{array}$ \\
\hline $\mathrm{SC}$ & $\begin{array}{r}-13.524 \\
-0.87\end{array}$ & $\begin{array}{r}-14.811 \\
-0.75\end{array}$ \\
\hline $\mathrm{TX}$ & $\begin{array}{r}-4.600 \\
-0.69\end{array}$ & $\begin{array}{r}-4.891 \\
-0.54\end{array}$ \\
\hline KY & $\begin{array}{r}-1.496 \\
-0.28\end{array}$ & $\begin{array}{r}-1.569 \\
-0.24\end{array}$ \\
\hline MD & $\begin{array}{r}-2.979 \\
-0.52\end{array}$ & $\begin{array}{r}-6.487 \\
-0.97\end{array}$ \\
\hline $\mathrm{OK}$ & $\begin{array}{r}2.407 \\
0.44\end{array}$ & $\begin{array}{r}2.178 \\
0.34\end{array}$ \\
\hline $\mathrm{TN}$ & $\begin{array}{r}-3.405 \\
-0.46\end{array}$ & $\begin{array}{r}-5.158 \\
-0.54\end{array}$ \\
\hline
\end{tabular}




$\begin{array}{lrr}\text { WV } & 3.051 & 3.654 \\ & 0.66 & 0.66 \\ \text { AZ } & 2.579 & 3.955 \\ & 0.73 & 0.7 \\ \text { CO } & 5.792 & 2.580 \\ & 1.96 & 0.71 \\ \text { ID } & 5.108 & 5.274 \\ & 1.38 & 1.2 \\ \text { MT } & 5.622 & 4.037 \\ & 2.05 & 1.18 \\ \text { NV } & 5.372 & 4.799 \\ & 1.57 & 0.97 \\ \text { NM } & 3.179 & 3.978 \\ & 0.73 & 0.74 \\ \text { UT } & 5.011 & 1.869 \\ & 1.71 & 0.53 \\ \text { WY } & 3.362 & 1.848 \\ & 0.99 & 0.45 \\ \text { CA } & 2.761 & -2.282 \\ & 1.27 & -0.82 \\ \text { OR } & 2.859 & 0.734 \\ & 1.01 & 0.22 \\ \text { WA } & 3.566 & 2.018 \\ & 1.52 & 0.69\end{array}$

Notes. The numbers for continuous variables show the number of standard deviations by which the dependent variable changes with respect to a one-standard-deviation increase in the variable. The numbers for dummy variables show the number of standard deviations by which the dependent variable changes with respect to a move from zero to one of the dummy variable. Robust t-statistics, clustered by states are presented in italics below the numbers.

The dependent variables are the change in the ESWI between 1899 and 1909 and again from 1909 to 1919 and the change in Labor Spending (in \$1967) per mining and manufacturing worker between 1903 and 1909 and again from 1909 to 1916 . The means are .077 for the changes in the ESWI and .25 for the labor spending measure with standard deviations of .073 and .43 respectively.

There are two observations for each state except Arizona, New Mexico, and Oklahoma, which did not have presidential voting in the first period. The values for most variables are from the beginning of the decade. Presidential voting for the early observation is from 1900 and from 1912 for the later observation. The democratic governor variable is from 1900 and 1909. The manufacturing size variables are from 1899 and 1909, the gainful employment shares for mining, manufacturing, and agriculture are from 1900 and 1910. The change in the governor and changes in party control of legislatures are for the periods 1900 to 1909 and 1910 to 1919. The data sources are described in Fishback and Kantor (2000) and the data are available from Price Fishback's website at the University of Arizona Department of Economics: http://economics.eller.arizona.edu/faculty/Fishback.aspx. 


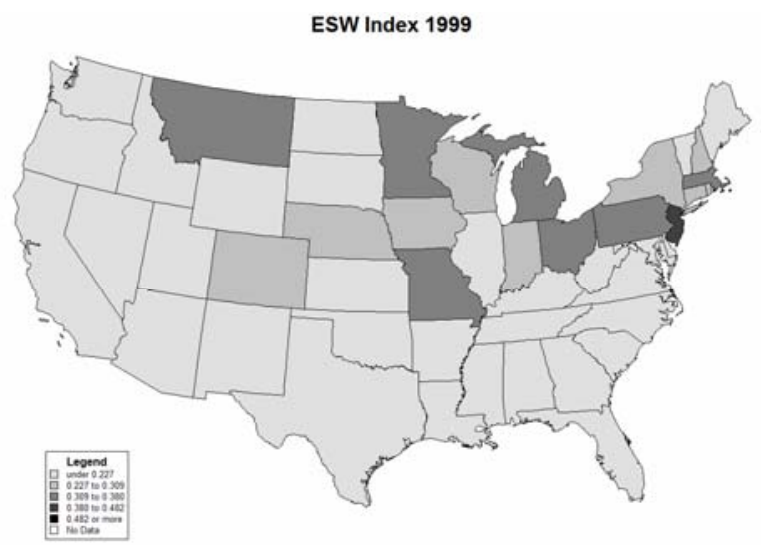

Figure 1

State Map of the ESW Index, 1999, 1909, 1914, 1919
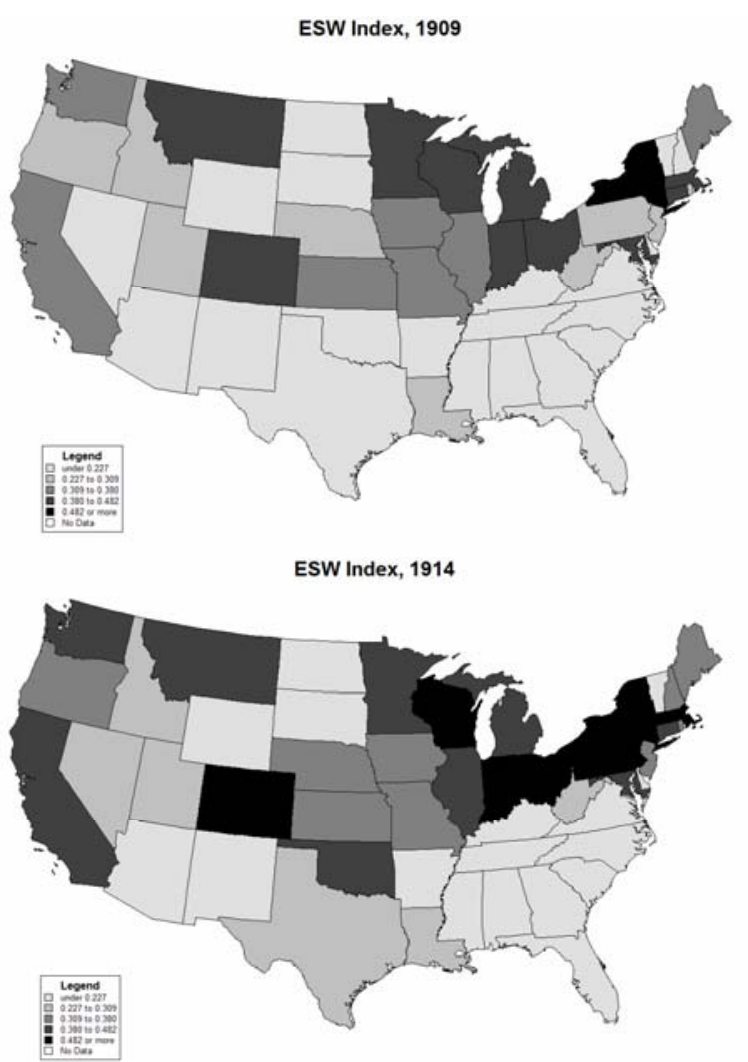

ESW Index, 1919
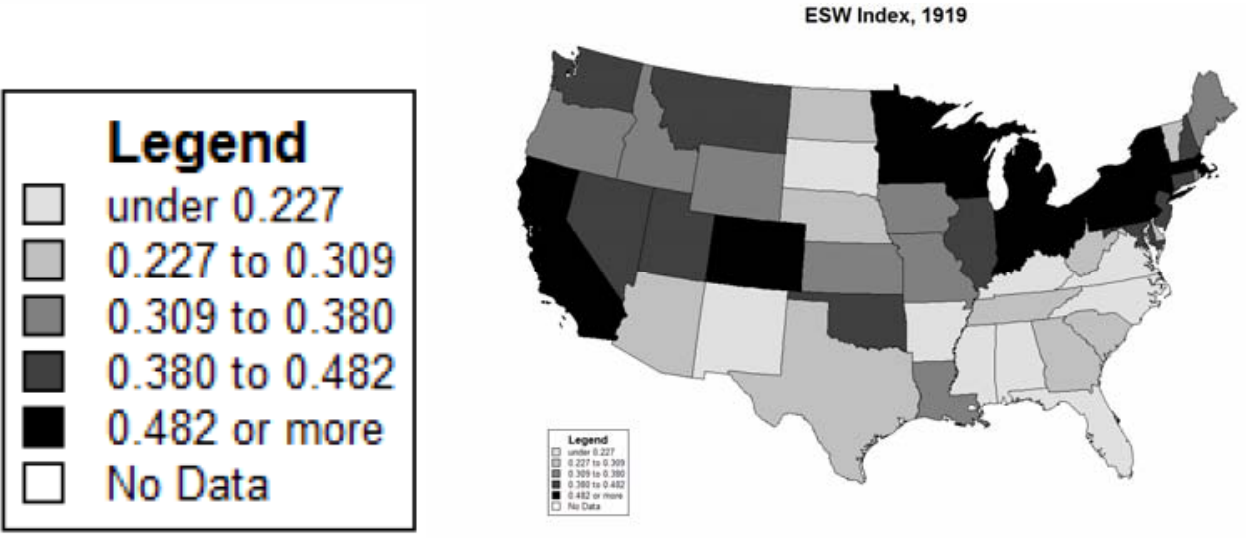
Figure 2

Scatter Plot of ESW Index in 1899 and 1899

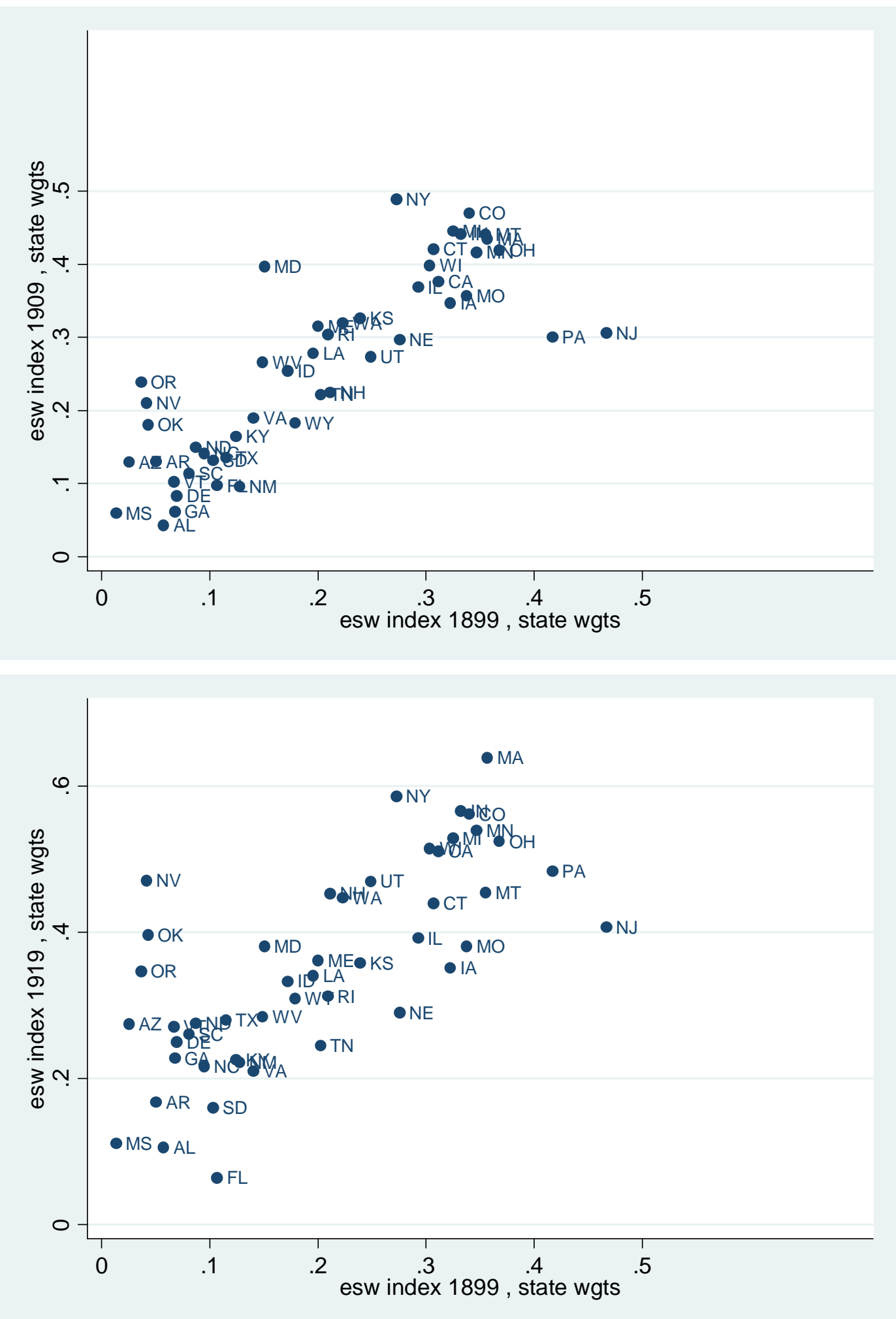


Pages of Labor Legislation Reported by the Department of Labor, 1904

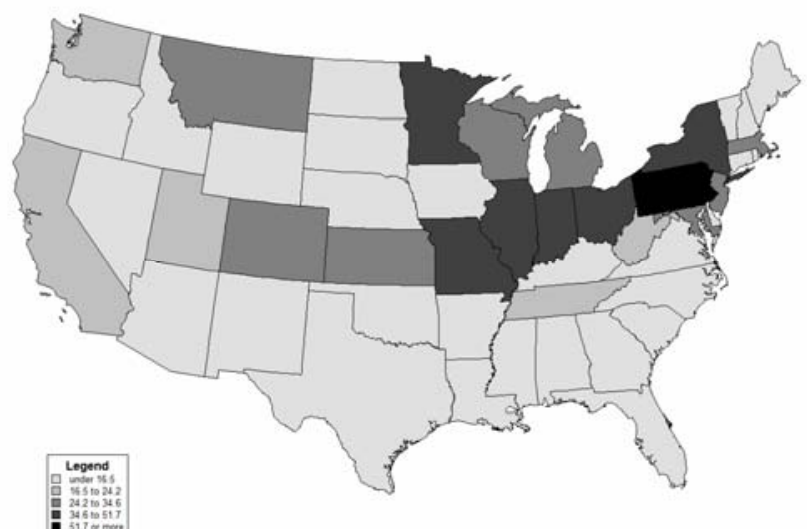

Pages of Labor Legislation Reported by Department of Labor, 1907

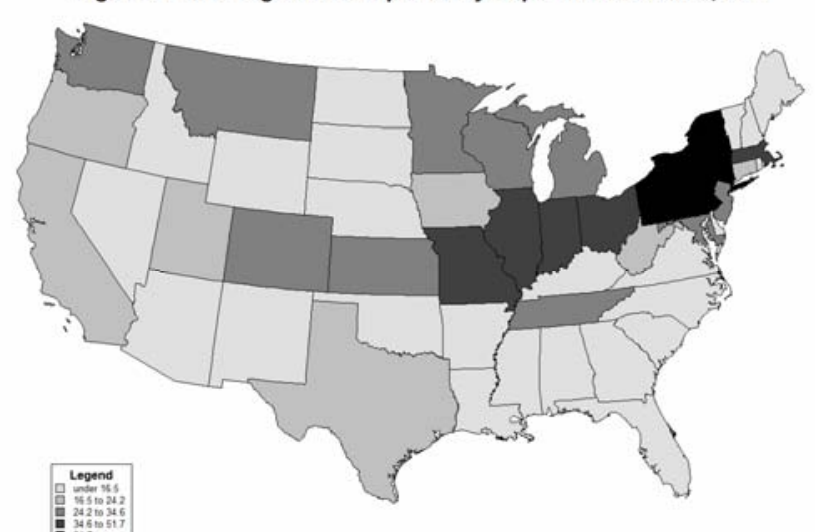

Pages of Labor Legislation Reported by Department of Labor, 1914 (without WC)

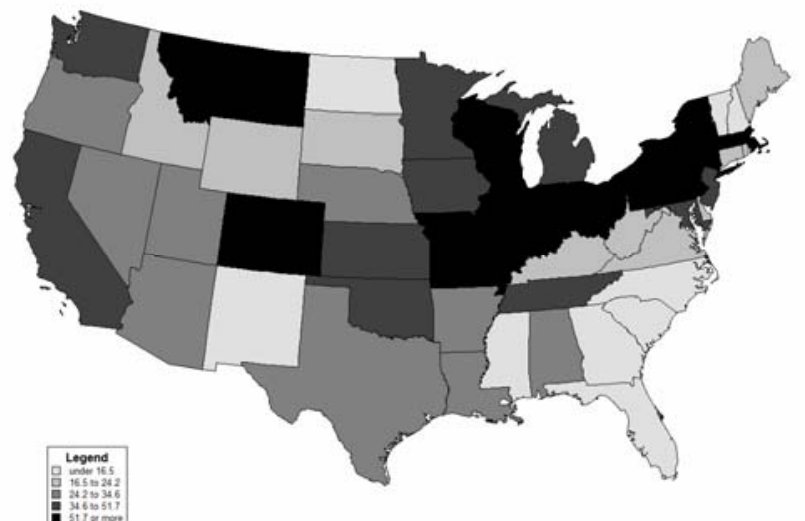

Figure 3

Maps Showing Pages of Labor Legislation Reported by the

Department of Labor
Legend

$\square$ under 16.5

$\square \quad 16.5$ to 24.2

$\square \quad 24.2$ to 34.6

$\square 34.6$ to 51.7

- 51.7 or more

$\square \quad$ No Data 
Figure 4

Scatter Plots of the Number of Pages

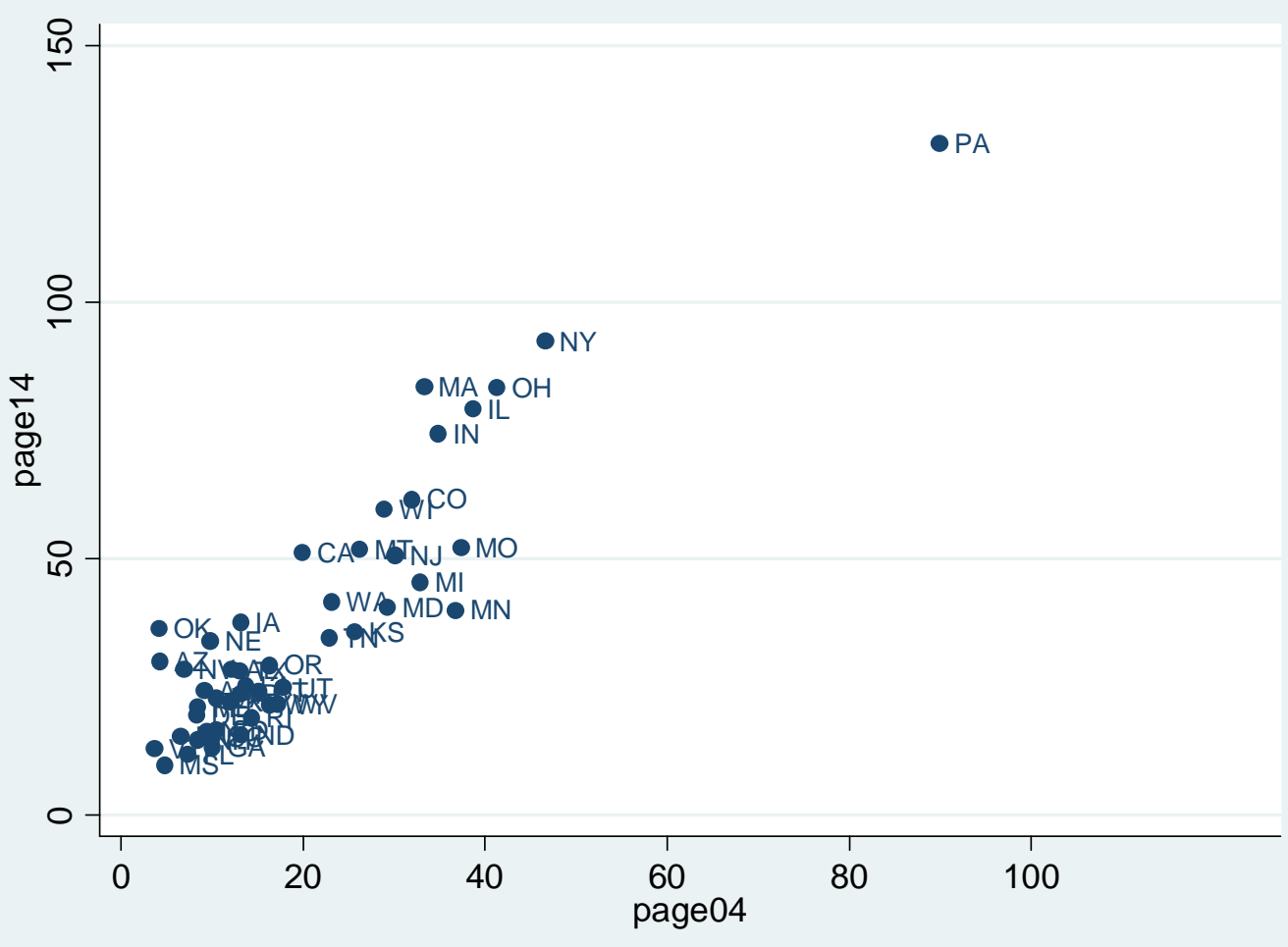


Labor Spending per Mining and Manufacturing Worker in 1967 Dollars, 1903

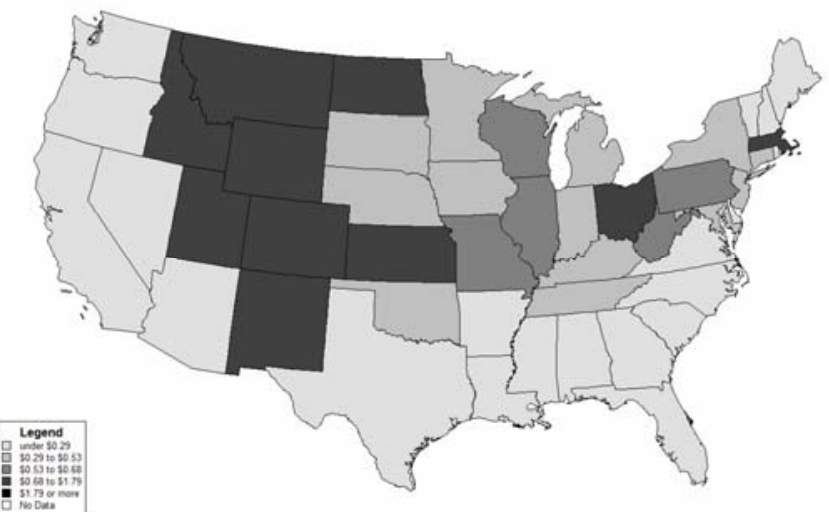

Labor Spending per Manufacturing and Mining Worker in 1967 Dollars, 1909

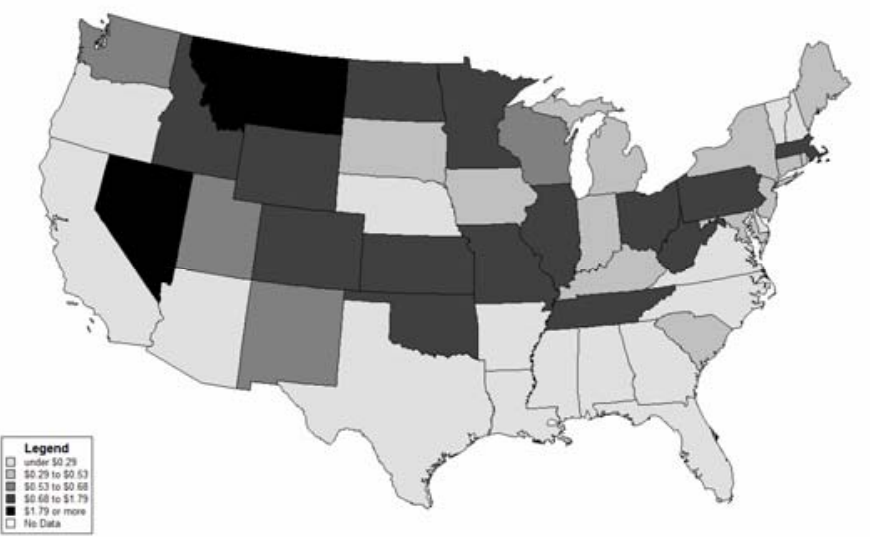

Labor Spending per Mining and Manufacturing Worker in 1967 Dollars, 1916

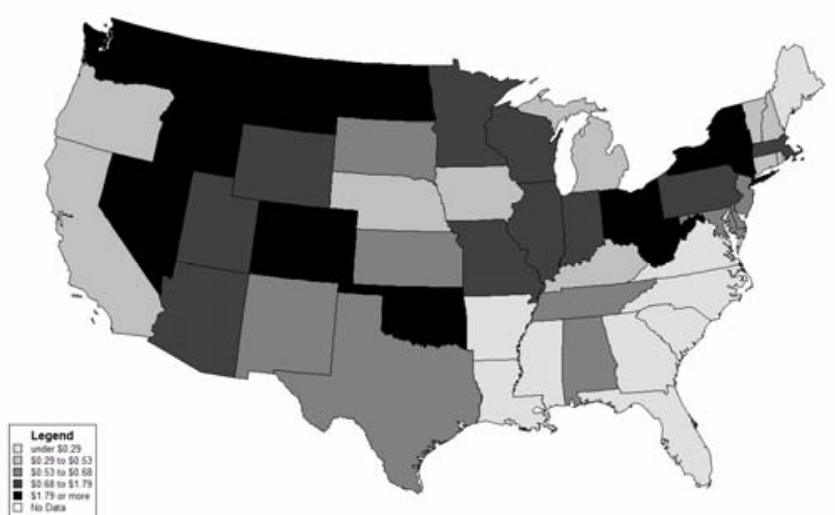

Figure 5

Maps of Labor Spending per

Mining and Manufacturing Worker in 1967 Dollars, 1903 
Figure 6

Scatter Plots of Labor Spending per Mining and Manufacturing Worker in 1967\$, 1903 and 1916

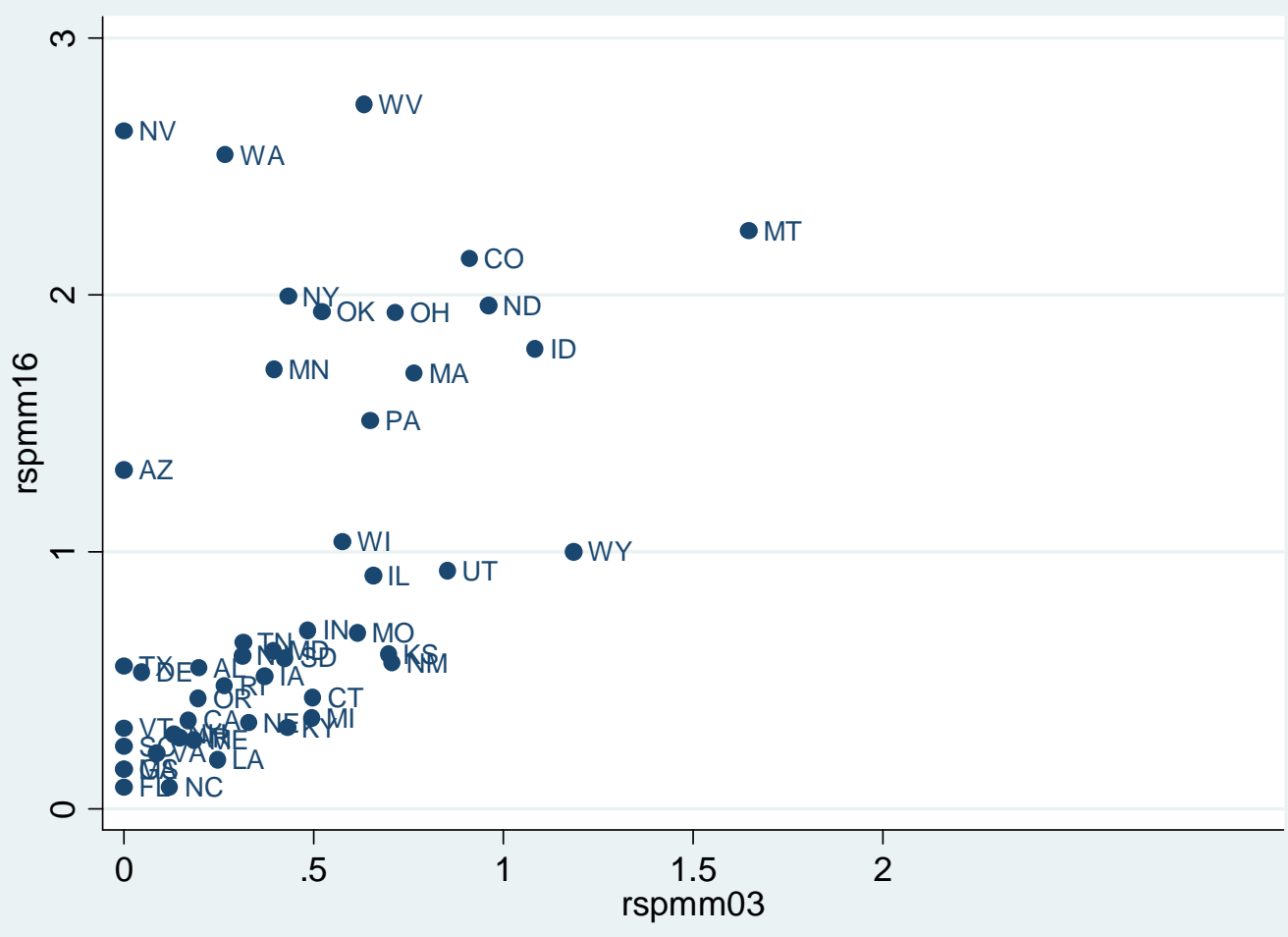




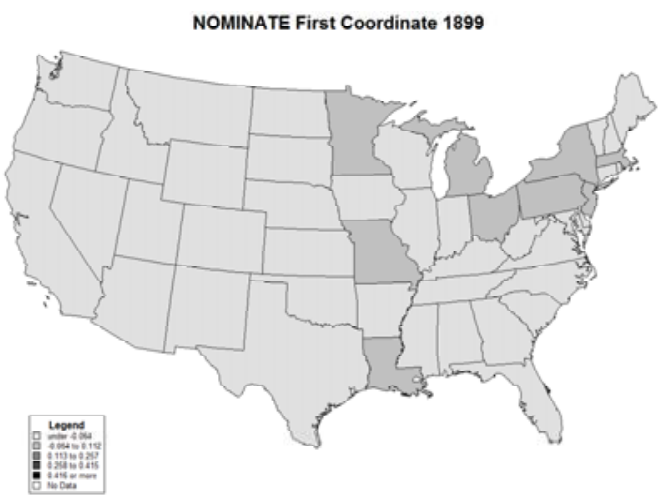

Figure 7

Maps of COORDINATE ONE
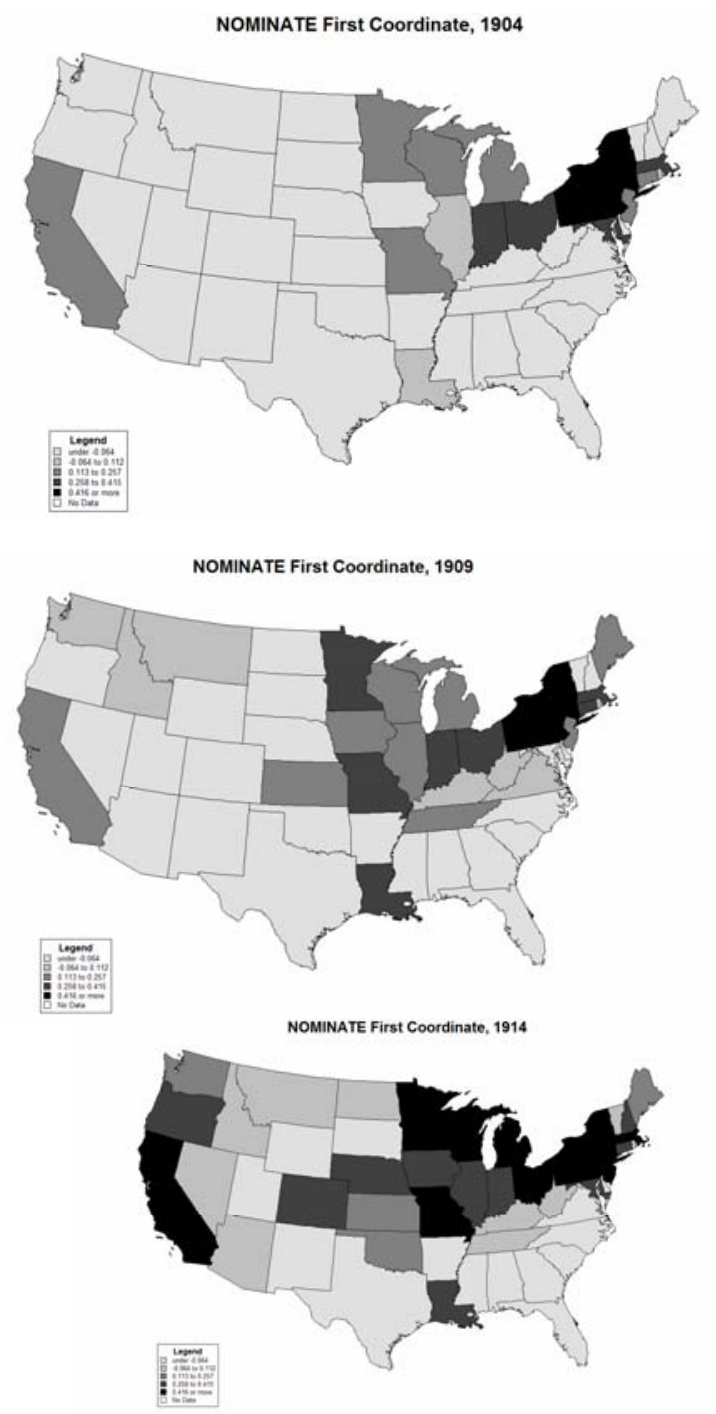

\section{Legend}

$\square$ under -0.064

$\square \quad-0.064$ to 0.112

$\square \quad 0.113$ to 0.257

$\square \quad 0.258$ to 0.415

- 0.416 or more

$\square$ No Data

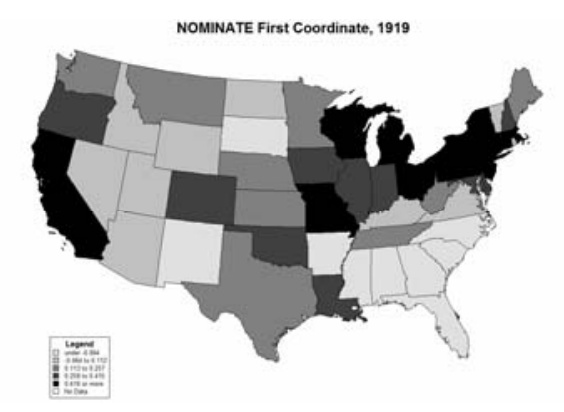




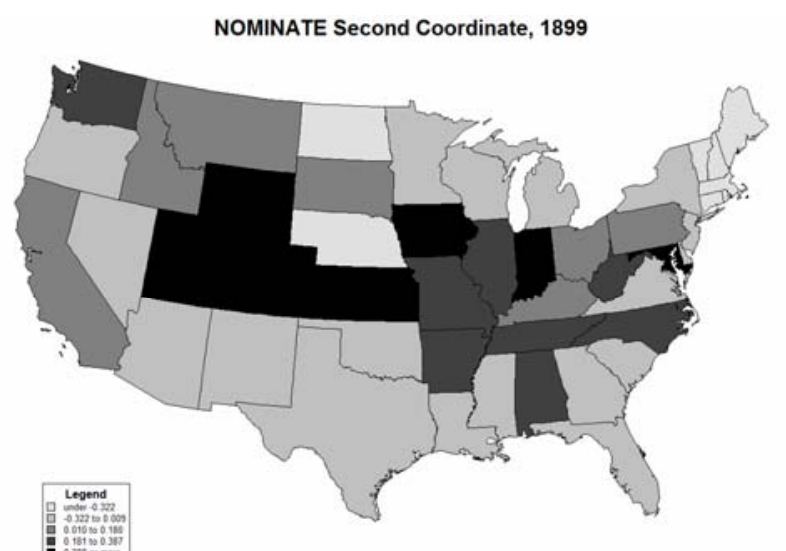

NOMINATE Second Coordinate, 1904

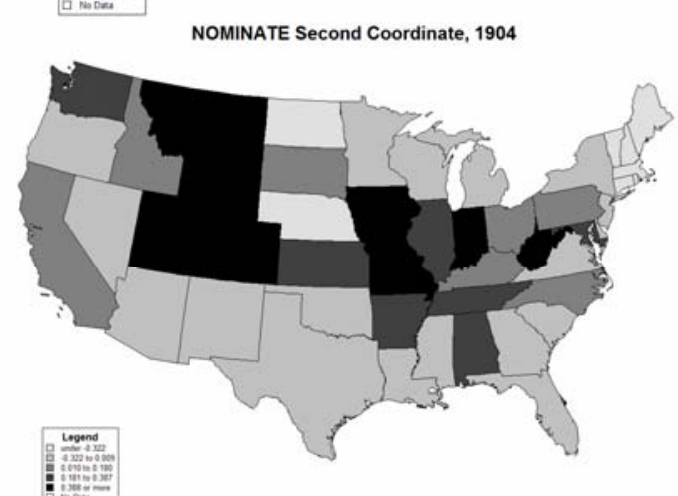

NOMINATE Second Coordinate, 1909

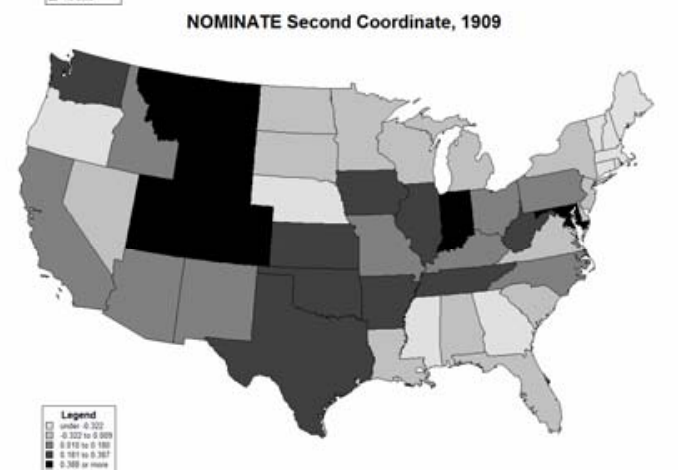

NOMINATE Second Coordinate, 1919

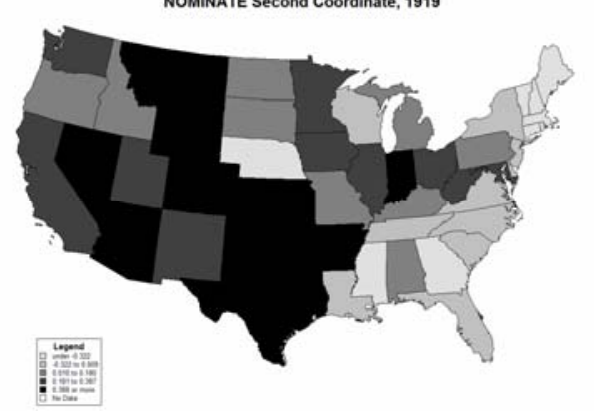

Figure 8

Maps of COORDINATE TWO

\section{Legend}

under -0.322

-0.322 to 0.009

$\square \quad 0.010$ to 0.180

$\square \quad 0.181$ to 0.387

- 0.388 or more

$\square$ No Data

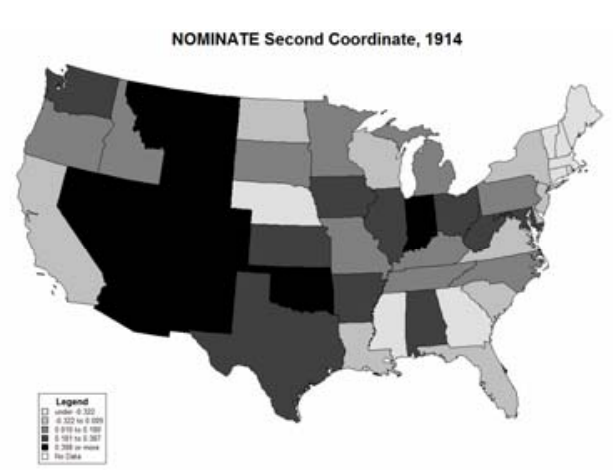


Figure 9

Scatter Plots of COORDINATE ONE Against COORDINATE TWO, 1899 and 1919
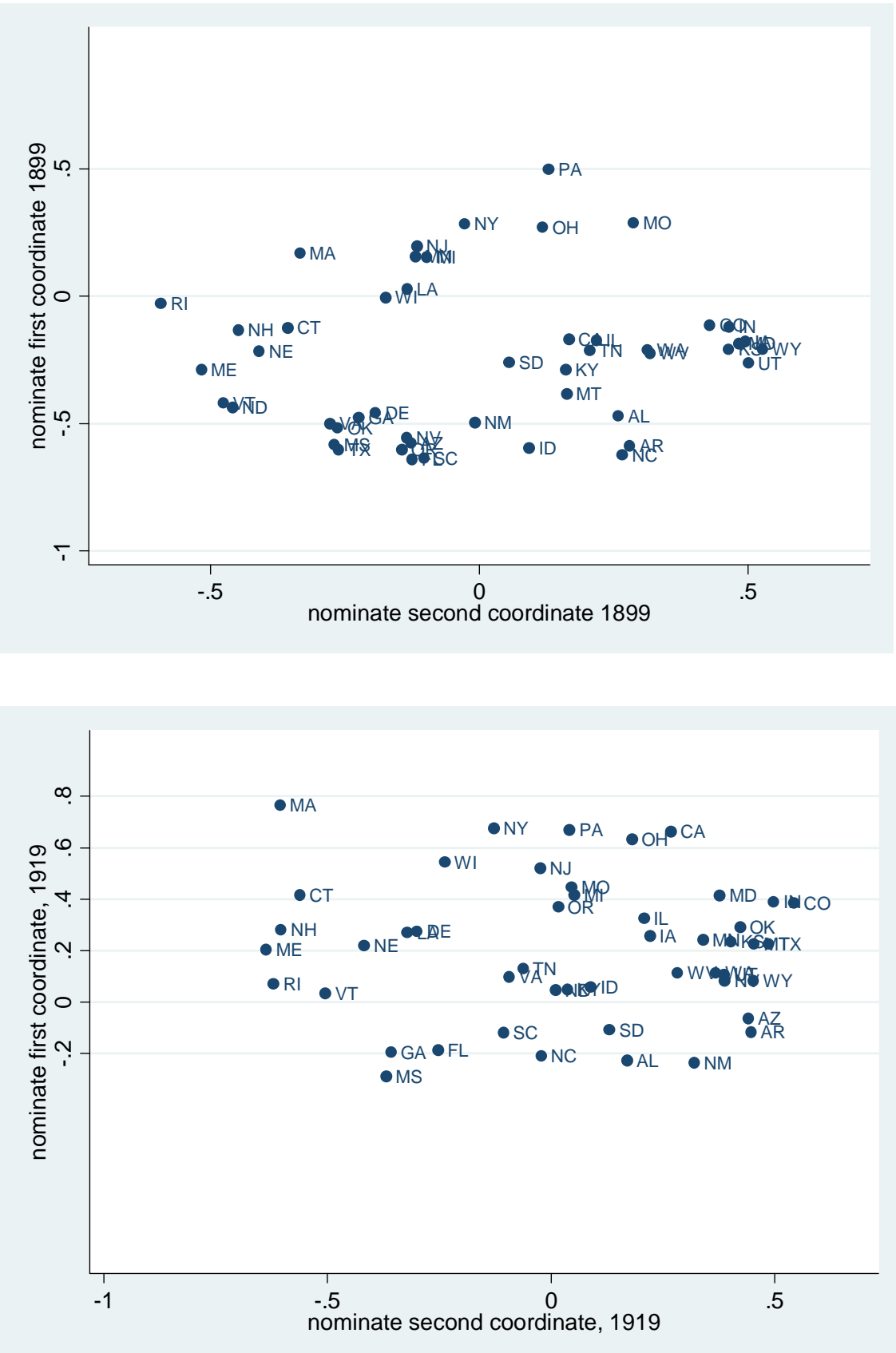
Figure 10

National EWSI and Labor Spending per Worker, 1899 to 1924

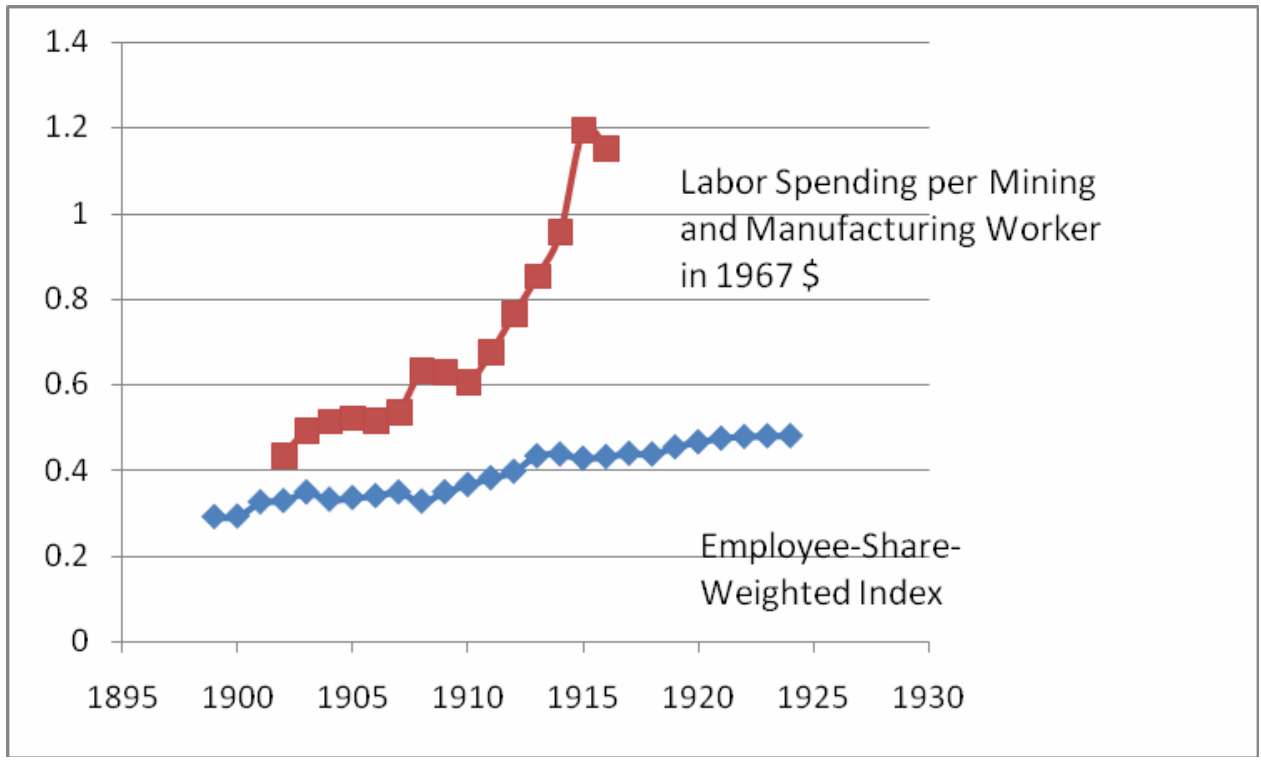


Appendix Table 1

Number of States with Each Type of Law, 1895, 1908, 1918, and 1924

[This Table is substantially reorganized to match the ESWI categories and differs in organization from the table that appeared in Holmes, Fishback, and Allen 2008]

\section{WORKPLACE ACTIVITY REGULATION}

\section{Factory Safety}

Sanitation/bathroom regulations

Ventilation

Guards required on machines

Electrical Regulations

Building Regulations

Other

Bakery Regulations

Sweatshop Regulations

Fire escapes

Factory Inspector

Factory accidents

Occupational disease reporting

\section{Mining Regulations}

Mine inspectors

Mine Safety Regulations: Employees/Individuals

$\begin{array}{rrrr}11 & 22 & 34 & 35 \\ 10 & 22 & 25 & 26 \\ 12 & 22 & 34 & 35 \\ 0 & 0 & 6 & 8 \\ 5 & 13 & 23 & 24 \\ 1 & 3 & 10 & 11 \\ 7 & 14 & 27 & 32 \\ 9 & 11 & 14 & 14 \\ 23 & 30 & 36 & 37 \\ 15 & 29 & 39 & 41 \\ 10 & 14 & 22 & 23 \\ 1 & 1 & 16 & 17\end{array}$

Mine Safety Regulations: Companies

No screening/fine if not weight coal

Mine Inspector fined for not doing job

Miners' Hospital and or Home

No Women and Children in Mines

Mine accidents Reporting

$\begin{array}{rrrr}23 & 30 & 33 & 33 \\ 18 & 23 & 30 & 32 \\ 22 & 30 & 33 & 35 \\ 14 & 21 & 22 & 23 \\ 9 & 13 & 17 & 18 \\ 4 & 5 & 5 & 5 \\ 25 & 31 & 35 & 35 \\ 19 & 26 & 33 & 32 \\ & & & \\ 20 & 32 & 45 & 45 \\ 4 & 7 & 6 & 6 \\ 3 & 21 & 36 & 39 \\ 7 & 28 & 30 & 30\end{array}$

\section{Railroad Regulations}

Safety Regulations

Railroad Inspectors

Railroad accidents reporting

Street Railroad safety regulations

Occupational Licensing

Railroad telegraph operators

Plumbers

Horseshoers

Chauffers

Aviators

Other

Motion Picture Operator

Barbers

Steam engineers (firemen)

Mine manager

Elevator operators

Railroad employees

Electricians

$\begin{array}{rrrr}3 & 1 & 1 & 2 \\ 9 & 19 & 22 & 23 \\ 2 & 5 & 6 & 6 \\ 0 & 1 & 27 & 36 \\ 0 & 0 & 2 & 6 \\ 0 & 0 & 2 & 2 \\ 0 & 0 & 8 & 8 \\ 1 & 13 & 16 & 16 \\ 11 & 16 & 17 & 17 \\ 7 & 11 & 13 & 16 \\ 1 & 2 & 2 & 2 \\ 1 & 1 & 1 & 1 \\ 0 & 1 & 2 & 4\end{array}$


Stevedores

$$
2
$$

2

2

HOURS REGULATION

Women's Hours

Night labor

General/All Employment

Mercantile

Mechanical

Textiles

$\begin{array}{rrrr}3 & 4 & 11 & 13 \\ 2 & 6 & 24 & 28 \\ 3 & 8 & 24 & 27 \\ 12 & 16 & 25 & 28 \\ 8 & 13 & 25 & 27 \\ & & & \\ 7 & 18 & 30 & 35 \\ 6 & 15 & 22 & 22 \\ 18 & 30 & 30 & 28 \\ 15 & 27 & 27 & 26 \\ 2 & 8 & 10 & 10 \\ 7 & 29 & 42 & 45\end{array}$

\section{Child hours law}

General

Mercantile

Mechanical

Textile

Other

Minimum Age for night labor for children

General Hours Laws

Textiles

Mines

Manufacture

Railroads

Street Railroads

Public Employment

Other

General Hours Law

Public Roads

$1 \mathrm{hr}$ for meals

$\begin{array}{rrrr}6 & 6 & 6 & 6 \\ 5 & 13 & 15 & 15 \\ 7 & 7 & 8 & 9 \\ 8 & 26 & 27 & 27 \\ 8 & 10 & 10 & 10 \\ 14 & 22 & 29 & 30 \\ 5 & 5 & 11 & 11 \\ 13 & 12 & 11 & 11 \\ 2 & 23 & 16 & 16 \\ 6 & 9 & 17 & 19\end{array}$

WOMEN AND CHILDREN ACTIVITY REGULATION

Child Labor

Child safety commission

$\begin{array}{rrrr}0 & 1 & 10 & 14 \\ 13 & 30 & 40 & 41 \\ 20 & 42 & 42 & 44\end{array}$

Children in manufacture/mercantile/mechanical jobs

Minimum Age

$\begin{array}{llll}17 & 33 & 40 & 42\end{array}$

Penalty for false certificate of age

Certificates of Age required for employment

Fine for children working to support idle parents.

No children cleaning or handling moving parts

No children in immoral jobs (acrobat) Is this street jobs?

No women and children in bars

6

Women's Regulation

Special accommodations (seats)

Earnings of married women belong to her

EMPLOYER LIABILITY AND WORKERS' COMPENSATION

Restates Common Law

General 
Railroads

Street Railroads

Mines

Can't require employees to sign contracts waiving

damages

Workers' Compensation Law

$\begin{array}{rrrr}16 & 31 & 32 & 32 \\ 1 & 8 & 7 & 7 \\ 1 & 4 & 4 & 4 \\ 14 & 25 & 28 & 28 \\ & & & \\ 0 & 0 & 37 & 42 \\ 15 & 17 & 15 & 17\end{array}$

STEAM BOILER INSPECTION

\section{UNIONIZATION AND BARGAINING}

Pro-Union

False use of union cards or employers' certificates

Incorporation of labor unions.

Labor organizations exempt from antitrust

$\begin{array}{llll}1 & 10 & 12 & 13\end{array}$

Strikes: Agreements not to work allowed

$\begin{array}{rrrr}3 & 5 & 7 & 10 \\ 11 & 14 & 15 & 17\end{array}$

Conspiracy vs. workmen (conspiring to prevent someone from working

Labor agreement is not a conspiracy

No blacklisting

$\begin{array}{lrrr}6 & 8 & 8 & 10\end{array}$

$\begin{array}{llll}14 & 23 & 25 & 25\end{array}$

Yellow dog contract (Not allowed to join a union as a condition of employment) (illegal for anyone to coerce

116

to join or not to join a union)

Prohibition on hiring armed guards

Misrepresentation about a strike or other job

characteristics

Limits on injunctions

Labor organizations--embezzlement of funds by

officers

Combinations of employers to fix wages illegal$$
0
$$

$42 \quad 43 \quad 44$

\section{Anti-Union}

Enticement fines

Interfere with or intimidate in railroads or workers

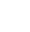

abandoning trains or obstructing track

Interference with railroad employees

Interference with street railroad employees

$\begin{array}{rrrr}14 & 9 & 9 & 9 \\ 4 & 1 & 1 & 2 \\ & & & \\ 4 & 6 & 7 & 7 \\ 15 & 16 & 19 & 21\end{array}$

No intimidation of miners

$$
0
$$

Anti-picketing

Anti-boycott

Anti-intimidation

Industrial police are legal

$\begin{array}{rrrr}0 & 2 & 2 & 6 \\ 3 & 7 & 5 & 5 \\ 19 & 23 & 26 & 27 \\ 1 & 9 & 19 & 22\end{array}$


Criminal Syndicalism (advocating violence or sabotage for political or industrial ends)

0

0

No Trespass without employer consent

BRIBERY, COERCION AND POLITICAL FREEDOMS

Foreman accepting fees for employment illegal

Bribing Employees

Coercion of Employees is illegal

Company Stores Cannot Gouge

Coercing the votes of employees illegal

Time off to Vote

BUREAU OF LABOR STATISTICS/DEPT. OF LABOR

STATE BOARD OF ARBITRATION, MEDIATION

REHABILITATION COMMISSION

INDUSTRIAL COMMISSION

FREE EMPLOYMENT OFFICES

ANTI-DISCRIMINATION

Cannot fire due to age only

Sex discrimination

Antidiscrimination

\section{PAYDAY REGULATIONS}

Nonpayment

Wages in cash

Wage payment frequency

Repayment of advance made by employer

1

$\begin{array}{llll}1 & 4 & 12 & 14\end{array}$

\section{0}

10

6

30

18

28

20

0

0

0

$$
0
$$$$
3
$$

3
1$$
1
$$$$
19
$$$$
20
$$

No forced contributions by employers

Railroad workers: Notice of reduction of wages required

Fine for no notice of discharge if employee has to give notice too

\section{HOLIDAYS}

No work on legal holidays

Labor Day a holiday

Sunday labor fines

MINIMUM WAGES

Minimum wage for public work

Minimum wage for women/children $(<18)$

Minimum Wage Commission

MISCELLANEOUS

illegal to desert a ship

Convict Labor Regulations

\section{Alien Labor}

Importing alien labor illegal

No aliens in public employment

Chinese labor illegal

\section{Employment Agents}


$\begin{array}{lrrrr}\text { Emigrant agent license } & 3 & 6 & 11 & 12 \\ \text { Regulation of Employment Agencies } & 11 & 25 & 35 & 42\end{array}$

Source: Holmes (2003, chapter 3). Includes all states as of 1912, Alaska, Hawaii, and the District of Columbia. 
Appendix Table Two

ESWI and Labor Regulation Spending per Mining and Manufacturing Worker (1967\$)

by State in Various Years

\begin{tabular}{|c|c|c|c|c|c|c|}
\hline STATNAME & $\begin{array}{c}\text { ESWI, } \\
1899\end{array}$ & $\begin{array}{c}\text { ESWI, } \\
1909\end{array}$ & $\begin{array}{c}\text { ESWI, } \\
1919\end{array}$ & $\begin{array}{c}\text { Spending } \\
\text { per } \\
\text { Worker } \\
1904\end{array}$ & $\begin{array}{c}\text { Spending } \\
\text { per } \\
\text { Worker, } \\
1909\end{array}$ & $\begin{array}{c}\text { Spending } \\
\text { per } \\
\text { Worker, } \\
1916\end{array}$ \\
\hline Alabama & 0.057 & 0.043 & 0.105 & $\$ 0.19$ & $\$ 0.24$ & $\$ 0.55$ \\
\hline Arizona & 0.025 & 0.129 & 0.274 & $\$ 0.00$ & $\$ 0.00$ & $\$ 1.32$ \\
\hline Arkansas & 0.050 & 0.130 & 0.167 & $\$ 0.19$ & $\$ 0.15$ & $\$ 0.28$ \\
\hline California & 0.311 & 0.376 & 0.510 & $\$ 0.16$ & $\$ 0.20$ & $\$ 0.34$ \\
\hline Colorado & 0.340 & 0.470 & 0.561 & $\$ 0.93$ & $\$ 1.45$ & $\$ 2.14$ \\
\hline Connecticut & 0.307 & 0.421 & 0.439 & $\$ 0.55$ & $\$ 0.49$ & $\$ 0.43$ \\
\hline Delaware & 0.070 & 0.084 & 0.250 & $\$ 0.05$ & $\$ 0.14$ & $\$ 0.53$ \\
\hline Florida & 0.107 & 0.097 & 0.064 & $\$ 0.00$ & $\$ 0.00$ & $\$ 0.08$ \\
\hline Georgia & 0.068 & 0.062 & 0.227 & $\$ 0.00$ & $\$ 0.00$ & $\$ 0.15$ \\
\hline Idaho & 0.172 & 0.254 & 0.333 & $\$ 1.07$ & $\$ 1.67$ & $\$ 1.79$ \\
\hline Illinois & 0.293 & 0.369 & 0.392 & $\$ 0.70$ & $\$ 0.77$ & $\$ 0.91$ \\
\hline Indiana & 0.332 & 0.442 & 0.566 & $\$ 0.48$ & $\$ 0.45$ & $\$ 0.70$ \\
\hline lowa & 0.322 & 0.347 & 0.351 & $\$ 0.39$ & $\$ 0.43$ & $\$ 0.52$ \\
\hline Kansas & 0.239 & 0.326 & 0.358 & $\$ 0.67$ & $\$ 0.81$ & $\$ 0.60$ \\
\hline Kentucky & 0.124 & 0.165 & 0.225 & $\$ 0.41$ & $\$ 0.47$ & $\$ 0.31$ \\
\hline Louisiana & 0.196 & 0.278 & 0.340 & $\$ 0.23$ & $\$ 0.15$ & $\$ 0.19$ \\
\hline Maine & 0.200 & 0.315 & 0.361 & $\$ 0.18$ & $\$ 0.33$ & $\$ 0.27$ \\
\hline Maryland & 0.151 & 0.397 & 0.381 & $\$ 0.44$ & $\$ 0.52$ & $\$ 0.62$ \\
\hline Massachusetts & 0.357 & 0.435 & 0.638 & $\$ 0.77$ & $\$ 1.08$ & $\$ 1.69$ \\
\hline Michigan & 0.325 & 0.445 & 0.528 & $\$ 0.48$ & $\$ 0.47$ & $\$ 0.35$ \\
\hline Minnesota & 0.347 & 0.416 & 0.539 & $\$ 0.40$ & $\$ 1.12$ & $\$ 1.71$ \\
\hline Mississippi & 0.013 & 0.060 & 0.110 & $\$ 0.00$ & $\$ 0.00$ & $\$ 0.15$ \\
\hline Missouri & 0.338 & 0.357 & 0.381 & $\$ 0.60$ & $\$ 0.79$ & $\$ 0.68$ \\
\hline Montana & 0.355 & 0.441 & 0.454 & $\$ 1.69$ & $\$ 2.11$ & $\$ 2.25$ \\
\hline Nebraska & 0.276 & 0.296 & 0.290 & $\$ 0.32$ & $\$ 0.26$ & $\$ 0.33$ \\
\hline Nevada & 0.042 & 0.210 & 0.470 & $\$ 0.00$ & $\$ 1.94$ & $\$ 2.64$ \\
\hline New Hampshire & 0.211 & 0.224 & 0.453 & $\$ 0.13$ & $\$ 0.12$ & $\$ 0.29$ \\
\hline New Jersey & 0.467 & 0.306 & 0.407 & $\$ 0.32$ & $\$ 0.40$ & $\$ 0.60$ \\
\hline New Mexico & 0.128 & 0.096 & 0.222 & $\$ 0.69$ & $\$ 0.58$ & $\$ 0.57$ \\
\hline New York & 0.272 & 0.489 & 0.586 & $\$ 0.43$ & $\$ 0.50$ & $\$ 1.99$ \\
\hline North Carolina & 0.095 & 0.142 & 0.217 & $\$ 0.12$ & $\$ 0.10$ & $\$ 0.08$ \\
\hline North Dakota & 0.087 & 0.149 & 0.275 & $\$ 1.03$ & $\$ 1.69$ & $\$ 1.96$ \\
\hline Ohio & 0.368 & 0.419 & 0.524 & $\$ 0.80$ & $\$ 0.99$ & $\$ 1.93$ \\
\hline Oklahoma & 0.043 & 0.180 & 0.396 & $\$ 0.42$ & $\$ 1.60$ & $\$ 1.93$ \\
\hline Oregon & 0.037 & 0.239 & 0.346 & $\$ 0.19$ & $\$ 0.15$ & $\$ 0.43$ \\
\hline Pennsylvania & 0.417 & 0.300 & 0.483 & $\$ 0.75$ & $\$ 0.81$ & $\$ 1.51$ \\
\hline Rhode Island & 0.209 & 0.304 & 0.312 & $\$ 0.26$ & $\$ 0.32$ & $\$ 0.48$ \\
\hline South Carolina & 0.081 & 0.114 & 0.260 & $\$ 0.00$ & $\$ 0.31$ & $\$ 0.24$ \\
\hline South Dakota & 0.103 & 0.131 & 0.160 & $\$ 0.40$ & $\$ 0.35$ & $\$ 0.59$ \\
\hline Tennessee & 0.203 & 0.221 & 0.245 & $\$ 0.31$ & $\$ 0.69$ & $\$ 0.65$ \\
\hline
\end{tabular}




$\begin{array}{lllllll}\text { Texas } & 0.115 & 0.135 & 0.280 & \$ 0.00 & \$ 0.11 & \$ 0.56 \\ \text { Utah } & 0.249 & 0.274 & 0.469 & \$ 0.84 & \$ 0.58 & \$ 0.93 \\ \text { Vermont } & 0.067 & 0.103 & 0.270 & \$ 0.00 & \$ 0.00 & \$ 0.31 \\ \text { Virginia } & 0.141 & 0.189 & 0.209 & \$ 0.08 & \$ 0.19 & \$ 0.22 \\ \text { Washington } & 0.223 & 0.319 & 0.447 & \$ 0.27 & \$ 0.57 & \$ 2.55 \\ \text { West Virginia } & 0.149 & 0.266 & 0.284 & \$ 0.64 & \$ 1.03 & \$ 2.74 \\ \text { Wisconsin } & 0.303 & 0.398 & 0.514 & \$ 0.56 & \$ 0.66 & \$ 1.04 \\ \text { Wyoming } & 0.179 & 0.183 & 0.310 & \$ 1.37 & \$ 1.42 & \$ 1.00\end{array}$

Notes. See text for discussion of how the variables were created. 


\section{Appendix Table Three \\ Labor Regulation COORDINATES ONE AND TWO and Number of Pages of Labor Regulation by State in Various Years}

\begin{tabular}{|c|c|c|c|c|c|c|c|c|}
\hline STATNAME & $\begin{array}{l}\text { ONE } \\
1899\end{array}$ & $\begin{array}{l}\text { ONE } \\
1909\end{array}$ & $\begin{array}{l}\text { ONE } \\
1919\end{array}$ & $\begin{array}{l}\text { TWO } \\
1899\end{array}$ & $\begin{array}{l}\text { TWO } \\
1909\end{array}$ & $\begin{array}{l}\text { TWO } \\
1919\end{array}$ & $\begin{array}{c}\text { Laws } \\
1907\end{array}$ & $\begin{array}{c}\text { Laws } \\
1914\end{array}$ \\
\hline Alabama & -0.471 & -0.211 & -0.226 & 0.259 & -0.022 & 0.17 & 14.47 & 28.33 \\
\hline Arizona & -0.577 & -0.386 & -0.064 & -0.127 & 0.025 & 0.441 & 5.88 & 29.94 \\
\hline Arkansas & -0.589 & -0.229 & -0.117 & 0.28 & 0.214 & 0.447 & 13.77 & 24.20 \\
\hline California & -0.169 & 0.139 & 0.662 & 0.167 & 0.032 & 0.268 & 20.67 & 51.19 \\
\hline Colorado & -0.114 & -0.114 & 0.385 & 0.429 & 0.429 & 0.543 & 34.48 & 61.56 \\
\hline Connecticut & -0.126 & 0.354 & 0.416 & -0.356 & -0.54 & -0.562 & 17.47 & 24.03 \\
\hline Delaware & -0.458 & -0.261 & 0.275 & -0.193 & -0.245 & -0.3 & 9.66 & 19.35 \\
\hline Florida & -0.641 & -0.187 & -0.186 & -0.125 & -0.254 & -0.253 & 6.99 & 11.81 \\
\hline Georgia & -0.477 & -0.329 & -0.195 & -0.224 & -0.348 & -0.358 & 10.52 & 13.24 \\
\hline Idaho & -0.597 & 0.022 & 0.057 & 0.093 & 0.095 & 0.089 & 15.29 & 23.61 \\
\hline Illinois & -0.174 & 0.224 & 0.326 & 0.218 & 0.361 & 0.208 & 44.14 & 79.10 \\
\hline Indiana & -0.12 & 0.272 & 0.389 & 0.465 & 0.542 & 0.498 & 41.34 & 74.38 \\
\hline lowa & -0.179 & 0.17 & 0.258 & 0.495 & 0.211 & 0.221 & 19.23 & 37.53 \\
\hline Kansas & -0.211 & 0.131 & 0.235 & 0.464 & 0.196 & 0.403 & 28.03 & 35.63 \\
\hline Kentucky & -0.289 & 0.063 & 0.05 & 0.161 & 0.028 & 0.037 & 16.03 & 22.14 \\
\hline Louisiana & 0.028 & 0.276 & 0.271 & -0.134 & -0.3 & -0.322 & 14.06 & 25.1 \\
\hline Maine & -0.288 & 0.151 & 0.205 & -0.516 & -0.623 & -0.637 & 9.45 & 21.08 \\
\hline Maryland & -0.187 & -0.118 & 0.414 & 0.483 & 0.474 & 0.377 & 34.19 & 40.48 \\
\hline Massachusetts & 0.167 & 0.346 & 0.765 & -0.333 & -0.605 & -0.606 & 44.06 & 83.40 \\
\hline Michigan & 0.153 & 0.171 & 0.416 & -0.097 & -0.102 & 0.052 & 32.71 & 45.37 \\
\hline Minnesota & 0.155 & 0.275 & 0.242 & -0.119 & -0.024 & 0.34 & 25.97 & 39.89 \\
\hline Mississippi & -0.584 & -0.525 & -0.288 & -0.269 & -0.38 & -0.369 & 5.59 & 9.70 \\
\hline Missouri & 0.287 & 0.407 & 0.447 & 0.287 & 0.051 & 0.046 & 44.38 & 52.11 \\
\hline Montana & -0.385 & 0.087 & 0.225 & 0.163 & 0.528 & 0.454 & 29.67 & 51.69 \\
\hline Nebraska & -0.217 & -0.208 & 0.22 & -0.409 & -0.335 & -0.418 & 14.84 & 33.98 \\
\hline Nevada & -0.557 & -0.551 & 0.084 & -0.135 & -0.131 & 0.388 & 9.66 & 28.33 \\
\hline New Hampshire & -0.134 & -0.104 & 0.28 & -0.448 & -0.427 & -0.604 & 10.19 & 14.67 \\
\hline New Jersey & 0.196 & 0.23 & 0.521 & -0.116 & -0.314 & -0.024 & 32.55 & 50.60 \\
\hline New Mexico & -0.497 & -0.485 & -0.236 & -0.008 & 0.057 & 0.32 & 5.84 & 15.2 \\
\hline New York & 0.283 & 0.664 & 0.676 & -0.027 & -0.116 & -0.128 & 59.51 & 92.34 \\
\hline North Carolina & -0.625 & -0.226 & -0.211 & 0.266 & 0.171 & -0.022 & 9.12 & 16.28 \\
\hline North Dakota & -0.438 & -0.433 & 0.048 & -0.459 & -0.276 & 0.01 & 12.41 & 15.60 \\
\hline Ohio & 0.27 & 0.27 & 0.633 & 0.118 & 0.118 & 0.181 & 42.41 & 83.23 \\
\hline Oklahoma & -0.518 & -0.284 & 0.291 & -0.263 & 0.32 & 0.423 & 3.53 & 36.26 \\
\hline Oregon & -0.602 & -0.209 & 0.37 & -0.144 & -0.393 & 0.016 & 21.62 & 29.22 \\
\hline Pennsylvania & 0.498 & 0.507 & 0.67 & 0.129 & 0.082 & 0.041 & 99.62 & 130.9 \\
\hline Rhode Island & -0.029 & -0.034 & 0.071 & -0.592 & -0.589 & -0.621 & 15.04 & 18.93 \\
\hline South Carolina & -0.636 & -0.379 & -0.119 & -0.103 & -0.066 & -0.106 & 10.11 & 15.18 \\
\hline South Dakota & -0.262 & -0.244 & -0.109 & 0.056 & 0.001 & 0.13 & 9.78 & 16.53 \\
\hline Tennessee & -0.215 & 0.189 & 0.129 & 0.205 & 0.189 & -0.062 & 24.86 & 34.5 \\
\hline
\end{tabular}




$\begin{array}{lcccccccc}\text { Texas } & -0.602 & -0.271 & 0.225 & -0.261 & 0.207 & 0.487 & 19.60 & 27.95 \\ \text { Utah } & -0.263 & -0.275 & 0.106 & 0.501 & 0.569 & 0.387 & 18.74 & 24.83 \\ \text { Vermont } & -0.42 & -0.42 & 0.035 & -0.476 & -0.477 & -0.505 & 4.48 & 12.90 \\ \text { Virginia } & -0.502 & 0.025 & 0.099 & -0.278 & -0.149 & -0.094 & 9.82 & 22.77 \\ \text { Washington } & -0.213 & 0.083 & 0.113 & 0.313 & 0.309 & 0.368 & 28.60 & 41.57 \\ \text { West Virginia } & -0.224 & 0.112 & 0.113 & 0.318 & 0.283 & 0.283 & 20.14 & 21.59 \\ \text { Wisconsin } & -0.006 & 0.256 & 0.543 & -0.174 & -0.15 & -0.238 & 33.78 & 59.58 \\ \text { Wyoming } & -0.209 & -0.2 & 0.084 & 0.527 & 0.523 & 0.452 & 16.36 & 21.46\end{array}$

Notes. See text for discussion of how variables were created.

*The page numbers for 1914 do not include pages of text devoted to Workers' Compensation Laws. 


\section{REFERENCES}

Acemoglu, Daron and Robinson, James (2006). Economic Origins of Dictatorship and Democracy. New York: Cambridge University Press.

Aldrich, M. (1997) Safety First: Technology, Labor, and Business in the Building of American Work Safety, 1870-1939. Baltimore: Johns Hopkins University Press.

Aldrich, M. (2006). Death Rode the Rails: American Railroad Accidents and Safety, 1828-1965. Baltimore: Johns Hopkins University Press.

Barro, Robert and Sala-i-Martin, Xavier (2004). Economic Growth. Second Edition. Cambridge, MA: The MIT Press).

Berry, William, Ringquist, Evan, Fording, Richard, and Hanson, Russell (1998) "Measuring Citizen and Government Ideology in the States." American Journal of Political Science 42: 327-48.

Botero, Juan, Djankov, Simon, La Porta, Rafel, Lpez-de-Silanes, Florencio, and Andrei Shleifer. (2004). "The Regulation of Labor." Quarterly Journal of Economics 119 (November): 1339-1382.

Boyer, George (1990). An Economic History of the English Poor Law, 1750-1850. New York: Cambridge University Press.

Brandeis, Elizabeth. (1966) "Labor Legislation." in John R. Commons and Associates, History of Labor in the United States, 1896-1932, volume 3, reprint of material published between 1916 and 1935. New York: Augustus Kelley Publishers.

Brandes, Stuart. (1976). American Welfare Capitalism, 1880-1940. Chicago: Univ. of Chicago Press.

Brody, David. (1980) Labor Embattled: History, Power, Rights. Champaign-Urbana IL: University of Illinois Press.

Brody, David. (1980) Workers in Industrial America: Essays on the $20^{\text {th }}$ Century Struggles. New York: Oxford University Press.

Brown, M., Christiansen, J., and Phillips, P. (1992) "The Decline of Child Labor in the U.S. fruit and vegetable canning industry: Law or Economics?” Business History Review 66 (Winter): 723770 .

Buffum, David (1992) "Workmen's Compensation: Passage and Impact." Ph.D. diss., University of Pennsylvania.

Burns, Ric, James Sanders, and Lisa Ades (2003). New York: An Illustrated History. New York: Knopf.

Chelius, James R. (1976) "Liability for Industrial Accidents: A Comparison of Negligence and Strict Liability Systems," Journal of Legal Studies 5 (June): 293-309. . (1977), Workplace Safety and Health: The Role of Workers' Compensation. Washington, DC: American Enterprise Institute.

Commons, John R. and Associates. (1966) History of Labor in the United States, 4 volumes, reprint of material published between 1916 and 1935. New York: Augustus Kelley Publishers.

Currie, Janet and Ferrie, Joseph (2000) "The Law and Labor Strife in the United States, 1881-1894." Journal of Economic History 60 (March): 42-66.

Dubofsky, Melvyn (1994) The State and Labor in Modern America. Chapel Hill, NC: University of North Carolina Press.

Eyestone, Robert. “Confusion, Diffusion, and Innovation.” American Political Science Review 71 (June): 441-447.

Feng, Yi. 2003. Democracy, Governance, and Economic Performance. Cambridge, MA: MIT Press.

Fishback, Price V. (1986) "Workplace Safety during the Progressive Era: Fatal Accidents in Bituminous Coal Mining, 1912-1923," Explorations in Economic History 23 (July): 269-298. (1987) "Liability Rules and Accident Prevention in the Workplace: Empirical Evidence from the Early Twentieth Century," Journal of Legal Studies 16 (June): 305-328. 
(1992) Soft Coal, Hard Choices: The Economic Welfare of Bituminous Coal Miners, 1890 to 1930. New York: Oxford University Press.

. (1998) "Operations of "unfettered" labor markets: Exit and voice in American labor markets at the Turn of the Century. Journal of Economic Literature 36 (June): 722-65.

(2006) "The Irony of Reform: Did Large Employers Subvert Workplace Safety Reform, 1869 to

1930." Corruption and Reform: Lessons from American Economic History. Chicago:

University of Chicago Press.

Fishback, Price V. and Kantor, Shawn.E. (2000) A Prelude to the Welfare State: The Origins of Workers' Compensation. Chicago: University of Chicago Press.

Fishback, Price, Higgs, Robert, Libecap, Gary, et. al. (2007) Government and the American Economy: A New History. Chicago: University of Chicago Press.

Freeman, Richard and Casey Ichinowski, Editors. (1989). When Public Sector Workers Unionize. Chicago, University of Chicago Press.

Friedman, Gerald (1998) State-Making and Labor Movements: France and the United States, 1876-1914. Ithaca, NY: Cornell University Press.

Friedman, Gerald (2000) "The Political Economy of Early Southern Unionism: Race, Politics, and Labor in the South, 1880-1953." Journal of Economic History 60 (June): 384-413.

Glaeser, Edward. and Shleifer, Andrei. (2003) "The Rise of the Regulatory State." Journal of Economic Literature 41 (June): 401-25.

Goldin, Claudia (1990) Understanding the Gender Gap: An Economic History of Women. New York: Oxford University Press.

Haines, Michael (2006) Historical, Demographic, Economic, and Social Data: The United States: 17902000. Inter-University Consortium for Political and Social Research. ICPSR 2896.

Holmes, Rebecca (2003) “The Impact of State Labor Regulations on Manufacturing Input Demand During the Progressive Era." Unpublished Ph.D. dissertation, University of Arizona, 2003. . (2005) "The Impact of State Labor Regulations on Manufacturing Input Demand During the Progressive Era, Dissertation Summary." Journal of Economic History 65 (June); 531-532.

Holmes, Rebecca and Fishback, Price (2005) "The Impact of State Labor Regulations on Manufacturing Input Demand During the Progressive Era." Unpublished working paper. University of Arizona, 2005.

Holmes, Rebecca, Fishback, Price, and Allen, Samuel. (2008). "Measuring the Intensity of State Labor Regulation During the Progressive Era" in Quantitative Economic History: The Good of Counting, edited by Joshua Rosenbloom. New York: Routledge, pp. 119-145.

Howell, Chris (2005) Trade Unions and the State: The Construction of Industrial Relations in Britain, 1890-2000. Princeton, NJ: Princeton University Press.

Howell, Chris. (1992) Regulating Labor: The State and Industrial Relations in Postwar France. Princeton, NJ: Princeton University Press.

Jacobs, David and Daniel Tope (2007). "The Politics of Resentment in the Post-Civil Rights Era: Minority Threat, Homicide, and Ideological Voting in Congress." American Journal of Sociology (March): 1458-94.

Kaufman, Bruce. (1993) The Origins and Evolution of the Field of Industrial Relations in the United States. Cornell Studies in Industrial and Labor Relations Number 25. Ithaca, NY: ILR Press.

Knack, Stephen and Philip Keefer. (1995). "Institutions and Economic Performance, Cross-Country Tests Using Alternative Institutional Measures.” Economics and Politics 7: 207-228.

Law, Marc T. \& Kim, Sukkoo, (2005). "Specialization and Regulation: The Rise of Professionals and the Emergence of Occupational Licensing Regulation," The Journal of Economic History 65 (August): 723-756.

Law, Marc and Mindy S. Marks (2009) "The Effects of Occupational Licensing Laws on Minorities: Evidence from the Progressive Era." Forthcoming at the Journal of Law and Economics 52 (May 2009). 
Lleras-Muney, Adriana (2002). "Were Compulsory Attendance and Labor Laws Effective? An Analysis from 1915 to 1939." Journal of Law and Economics 45 (October): 401-435.

Lubove, Roy. (1967) "Workers' Compensation and the Prerogatives of Voluntarism." Labor History 8 (Fall): 227-54.

Margo, Robert and Finegan, Aldrich. (1996) "Compulsory Schooling Legislation and School Attendance in Turn of the Century America: A "Natural Experiment' Approach.” Economic Letters 53 (October): 103-10.

McEvoy, Arthur. 1995. "The Triangle Shirtwaist Fire of 1911: Social Change, Industrial Accidents, and the Evolution of Common-Sense Causality." Law and Social Inquiry 20 (Spring): 621-51.

Moehling, Carolyn (1999) "State Child Labor Laws and the Decline of Child Labor," Explorations in Economic History 36 (January): 72-106.

Montgomery, David. (1987) The Fall of the House of Labor: The Workplace, the State, and American Labor Activism, 1865-1925. New York: Cambridge University Press.

Moss, David (1996) Socializing Security: Progressive-Era Economists And The Origins Of American Social Policy. Cambridge, MA: Harvard University Press.

Mulligan, Casey and Shleifer. Andrei. (2004) "Population and Regulation." NBER Working Paper No. 10234. Cambridge, MA: National Bureau of Economic Research, January.

Munck, Gerardo. 2003. "Measures of Democracy, Governance, and Rule of Law: An Overview of Cross-National Data Sets." Paper prepared for World Bank workshop on "Understanding Growth and Freedom from the Bottom Up." Available at http://siteresources.worldbank.org/INTMOVOUTPOV/Resources/21042151148063363276/071503 Munck.pdf

Nonnenmacher, Tomas (2002). Patterns of Reform and Regulation in the States: 1880-1940. Working Paper. Allegheny College. Presented in Poster Session at Economic History Association Meetings.

Orloff, Ann. (1983). "Labor and the State: Labor Legislation in America, 1897-1978: A Time-series Analysis." Paper presented at the annual meetings of the American Sociological Association.

Orloff, Ann Shola and Skocpol, Theda. "Why Not Equal Protection? Explaining the Politics of Public Social Spending in Britain, 1900-1911, and the United States, 1880s-1920." American Sociological Review 49 (December 1984): 726-750.

Pavalko, Eliza. (1989) 'State Timing of Policy Adoption: Workmens' compensation in the United States, 1909-1929." American Journal of Sociology 95 (November): 592-615.

Phelan, Craig. (2007). Trade Union Revitalisation: Trends and Prospects in 34 Countries. New York: Peter Lang Publishing.

Poole, Keith T. "Non-Parametric Unfolding of Binary Choice Data." Political Analysis, 8:211-237, 2000.

Poole, Keith T. and Howard Rosenthal. 1997. Congress: A Political-Economic History of Roll Call Voting. New York: Oxford University Press.

Poole, Keith T. and Howard Rosenthal. 1991. "Patterns in Congressional Voting." American Journal of Political Science. 35: 228-278.

Poole, Keith T. (2005) Spatial Models of Parliamentary Voting. New York: Cambridge University Press.

Provost, Colin. (2006). "The Politics of Consumer Protection: Explaining State Attorney General Participation in State Lawsuits.” Political Research Quarterly 59 (December): 609-618.

Rosenbloom, Joshua (2002). Looking for Work, Searching for Workers: American Labor Markets During Industrialization. New York: Cambridge University Press.

Rosenbloom, Joshua. 1998. "Strikebreaking and the Labor Market in the United States, 1881-1894. Journal of Economic History 58 (March): 183-205.

Sanderson, A. (1974) "Child-Labor Legislation and the Labor Force Participation of Children," Journal of Economic History, 34 ( March): 297-299. 
Simmons, Beth and Zachary Elkins. (2004). "The Globalization of Liberalization: Policy Diffusion in the International Political Economy." The American Political Science Review 98 (February): 171-189.

Stein, Leon (1962) The Triangle Fire. New York: J.B. Lippincott Company.

Tope, Daniel. "The Politics of Union Decline." Ph.D. Dissertation. Columbus, OH: The Ohio State University.

Troy, Leo (1965) Trade Union Membership, 1897-1962, National Bureau of Economic Research Occasional Paper No. 92. New York: Columbia University Press.

U.S. Bureau of the Census. (1902). Twelfth Census of the United States: 1900, Manufactures, volume 7. Washington, DC: Government Printing Office.

(1903) Twelfth Census of the United States, 1900, Population Part 1, volume 1. Washington, DC: Government Printing Office.

(1904) Twelfth Census of the United States, 1900, Special Report -- Occupations. Washington, DC: Government Printing Office.

(1913) Thirteenth Census of the United States: 1910, Population, volume 1; Occupations, volume 4, Manufactures, volumes 8 and 9. Washington, DC: Government Printing Office.

. (1917) Abstract of the Census of Manufactures, 1914. Washington, DC: Government Printing Office.

. (1923) Fourteenth Census of the United States: 1920, Population, volumes 1 and 4; Manufactures, volume 8. Washington, DC: Government Printing Office.

(1928) Biennial Census of Manufactures, 1925. Washington, DC: Government Printing Office.

(1933) Fifteenth Census of the United States: 1930, Manufactures, volumes 1 and 3; Population, volumes 2 and 5. Washington, DC: Government Printing Office.

. (1975) Historical Statistics of the United States, Colonial Times to 1970. Washington, DC: Government Printing Office.

U.S. Department of Commerce (1914) Statistical Abstract of The United States, 1913, Thirty-Six

Number. Washington DC, Government Printing Office.

U.S. Department of Commerce, (1924) Statistical Abstract of The United States, 1923, Fourty-Sixth

Number. Washington DC, Government Printing Office.

U.S. Bureau of Labor Statistics (1914) "Labor Laws of the United States, with Decisions of Courts Relating Thereto." Bulletin of the United States Bureau of Labor Statistics No. 148. 2 parts.

Washington: GPO.

U.S. Bureau of Labor Statistics (1925) "Labor Laws of the United States, with Decisions of Courts

Relating Thereto." Bulletin of the United States Bureau of Labor Statistics No. 370.

Washington: GPO.

U.S. Commissioner of Labor. (1986) "Labor Laws of the United States." Second Special Report of the Commissioner of Labor. Washington: GPO.

U.S. Commissioner of Labor. (1904). "Labor Laws of the United States with Decisions of Courts Relating Thereto." Tenth Special Report of the Commissioner of Labor. Washington: GPO.

U.S. Commissioner of Labor. (1908) "Labor Laws of the United States with Decisions of Courts Relating Thereto, 1907." Twenty-Second Annual Report of the Commissioner of Labor. Washington: GPO.

U.S. Department of Labor. (1962) Growth of Labor Law in the United States. Washington DC, US Government Printing Office.

U.S. Supreme Court. 1905. Lochner v. New York. 198 U.S. 45. Downloaded from http://straylight.law.cornell.edu/supct/cases/name.htm, on August 18, 2005.

Von Drehle, David. 2003. Triangle: The Fire that Changed America. New York: Atlantic Monthly Press.

Walker, Jack. 1969. "The Diffusion of Innovations Among the American States." The American Political Science Review 63 (September ): 880-899. 
Wallace, Michael, Rubin, Beth, and Smith, Brian (1988). “American Labor Law: Its Impact on Working-Class Militancy, 1901-1980.” Social Science History 12 (Spring): 1-29.

Weinstein, James. (1967) "Big Business and the Origins of Workmens' Compensation." Labor History 8 (Spring): 156-74. . (1968). The Corporate Ideal in the Liberal State: 1900-1918. Boston: Beacon Press.

Whaples, Robert (1990a) "Winning the Eight-Hour Day, 1909-1919," Journal of Economic History 50 (June): 393-406. . (1990b) "The Shortening of the American Work Week: An Economic and Historical Analysis of Its Context, Causes, and Consequences," PhD. dissertation, University of Pennsylvania.

Wiebe, Robert (1962) Businessmen and Reform: A Study of the Progressive Movement. Cambridge, MA: Harvard University Press.

Witte, Edwin (1932) The Government in Labor Disputes. New York, McGraw-Hill.

Wolman, Leo (1936). The Ebb and Flow of Trade Unionism. New York, National Bureau of Economic Research.

Wright, Gavin (1986). Old South, New South: Revolutions in the Southern Economy Since the Civil War. New York: Basic Books. 


\section{ENDNOTES}

${ }^{1}$ For examples of recent political science articles that cite Walker and various other metrics for measuring policy and attitudes in an empirical settings, see Provost (2006) and Simmons and Elkins (2004). Among economic historians, Tomas Nonnenmacher (2002) has used Walker's information to develop alternative metrics.

${ }^{2}$ For example, see the work of Jacobs and Tope (2005) on changes in crime and the influx of minorities into areas and their influence on liberal voting records in Congress..

${ }^{3}$ The Heritage Foundation posts the latest version of the Index of Economic Freedom at its website, http://www.heritage.org/Index/. Freedom House posts historical listings of their scores in excel files at $\mathrm{http}: / / \mathrm{www}$.freedomhouse.org/template.cfm?page $=1$. An overview of these measures was reported in a World Bank working paper by Gerardo Munck (2003) at http://siteresources.worldbank.org/INTMOVOUTPOV/Resources/21042151148063363276/071503_Munck.pdf. For examples of empirical studies that use these measures see Acemoglu and Robinson (2006), Knack and Kiefer (1995), Feng (2003), Barro and Sala-i-Martin (2004, 526-9), and sources cited there.

${ }^{4}$ For examples, see Friedman $(1998,2002)$ on the U.S. and France and the role of the South within the United States, Rosenbloom $(2002,1998)$ on the development of U.S. regional and interregional labor markets and strike activity. For discussions of the role of the state in U.S. labor relations in the early twentieth century, see Brody (1980), Montgomery (1987), and Dubofsky (1994). Brody (2005), and Tope (2007) discuss the interaction between government policies and the decline of unionism in the United States. International comparisons illustrate the importance of the state. See Howell $(1992,2005)$ on the role played by governments in industrial relations in France, and Britain and the volume on 34 countries edited by Phelan (2007).

${ }^{5}$ In the area of labor laws, Fishback and Kantor (2000 and 1995) and Allen (2005) developed summary measures designed to capture the generosity of workers' compensation benefits. In a similar fashion, Boyer (1990) constructed a variety of measures of the nature of poor relief for children in Britain during the Industrial Revolution. For other examples, see Currie and Ferrie, 2000; Eyestone 1977; Botero, et. al. 2004, and the papers in Freeman and Ichniowski (1989). Wallace, Rubin, and Smith (1988) used information from an unpublished working paper by Ann Orloff (1983) to develop a labor law count of "pro-labor laws," but we have not been able to find a measure of that count as yet.

${ }^{6}$ See Brandeis (1966). For a discussion of the role played by institutional labor economists see Moss (1996).

${ }^{7}$ This finding helps explain why many studies have found relatively small effects of several forms of labor regulation. For example, see Moehling (1999), Sanderson (1974), Osterman (1979), Brown Christiansen, and Phillips (1982), and Carter and Sutch (1996a) on child labor, Goldin (1990) and Whaples (1990a, b) on women's hours laws, Fishback and Kantor (2000), Buffum (1992), Chelius (1976, 1977), Fishback (1986, 1987, 1990), and Aldrich (1997) on workers' compensation and employer liability laws, Fishback $(1986,1990)$ on coal mining regulations, and Aldrich $(1997,2006)$ on safety regulations in manufacturing, mines, and railroads. Child labor legislation had little impact on employment of children, but Margo and Finegan (1996) and Lleras-Muney (2002) find that school attendance legislation did significantly raise the rate of school attendance. A number of regulations had larger impact. Here we are citing findings of limited impact.

${ }^{8}$ The exceptions were railroads, maritime workers and other workers who routinely travelled across state boundaries when they worked. Yet, as will be seen below the states also adopted regulations of railroads. For more detail on railroads, see Aldrich $(1997,2006)$.

${ }^{9}$ For recent quantitative studies of occupational licensing see Law and Kim (2005) and Law and Marks (2009).

${ }^{10} \mathrm{~A}$ longer description of the ESWI with comparisons to the other methods for summing the laws is provided in Holmes, Fishback, and Allen (2008). 
${ }^{11}$ For the licensing categories we used the shares of people in the profession from that national census.

${ }^{12}$ We explored use of two other denominators, the total number of workers in gainful employment in 1900 as the base and the number of workers gainfully employed in mining and manufacturing. These two measures were correlated with the employment base in the text at levels above 0.8 and we don't believe they will change the conclusions much.

${ }^{13}$ The 1905 Lochner v. New York_Supreme Court decision that declared unconstitutional limits on bakers' hours in New York chilled efforts to establish wages and hours limits for male workers for some time.

${ }^{14} \mathrm{We}$ also need to consider the issue of what weight to give to other hours laws for men in other industries after the Lochner decision. We plan to work on this issue further.

${ }^{15}$ The coverage of the general hours laws and industry-specific hours laws is extremely confusing and we are still working on better ways to understand situations where there appears to be overlap in coverage.

${ }^{16} \mathrm{We}$ do all of the weighting by employment share within the subcategory indexes, so we do not need to weight again when summing across subcategories to develop the general index.

${ }^{17}$ Recent popular media that oversell the role of the Triangle Shirtwaist Fire include von Drehle (2003) and the widely seen PBS special on the history of New York and its companion volume by Burns, Sanders, and Ade (2003). Stein (1962), McEvoy (1995), and Fishback 2006 offer discussions that show more fully the extent of regulation before and after the fire.

${ }^{18} \mathrm{We}$ developed a rough count of the number of characters on a standard line for each volume by measuring the word employer, which was 1.3 millimeters in length in all volumes and dividing into the width of the page (11.1 millimeters in the 1896, and 9.2, 9.4, and 9.5 millimeters in the 1904, 1907, and 1914 volumes). We then counted the lines on a full page of text (68 in 1896, 65 in 1904, 66 in 1907, and 67 in 1914. We adjusted for the amount of text for each state on the beginning and ending pages of their sections in the book. This is still a rough measure because we did not adjust for spacing in the pages caused by law titles or for footnotes, of which there were not many. The BLS also reported on laws in 1925 but provided abbreviated descriptions of some laws when they had changed little from the 1914 volume; therefore, we could not use the information effectively.

${ }^{19} \mathrm{We}$ are considering incorporating some type of $\mathrm{H}$-index to capture diversity of industries when trying to explain the indices, and also controlling for the diversity in regressions on productivity, hours, and earnings.

${ }^{20}$ The measure in the text is a summary measure that combines all aspects of labor administration and enforcement. We have tried to separate out the specific appropriations for inspections (even to the level of differences for mining and factory inspectors) as opposed to administration for all of the states. We have succeeded so far in making this separation for only a subset of the states. In several states the appropriations are not separated into specific categories. Since our focus is on comparisons across all states we use the broadest measure of labor administration, which is comparable across states.

${ }^{21}$ The number employed in mining and manufacturing comes from the occupational information reported in the population Censuses of 1900, 1910, 1920, and 1930 (U.S. Bureau of the Census,1902, vol. 2, 508; 1913, vol. 4, 44-45; 1923, vol. 4, 48; 1933, vol 5, 54). To get values in the intervening years we use a straight-line interpolation between census years. The number gainfully employed includes agricultural workers and thus overstates the number of workers who were likely to be covered by labor regulations. We have explored dividing by the number of gainfully employed workers, which includes a larger number of workers in agriculture. It turns out that the cross-sectional correlations between spending per mining and manufacturing workers and the spending per gainfully employed worker are above .86 in 1903, 1909, and 1916. The cross-sectional correlations in the changes in the two measures between 1903 and 1909, 1903 and 1916, and 1909 and 1916 are all above 0.88 .

Therefore, we only report the measure divided by the mining and manufacturing workers in the text. 
${ }^{22}$ We have computerized information on fines for many specific laws, but we have not yet determined a way to incorporate them into the analysis. One reason we have not pursued this further is that in situations where fines were high, enforcers appeared to be less willing to impose them.

${ }^{23}$ Rebecca Holmes $(2003,2005)$ used principal component analysis to perform a similar data mining exercise with the law data in her dissertation. We switched to the Optimal Classification measure because factor analysis is better suited to settings where the variables analyzed are continuous, while the procedures that create the COORDINATE measures are specifically designed for variables that are zero-one in nature.

${ }^{24}$ We estimated the COORDINATES using the Optimal Classification procedure used by Poole and Rosenthal and described on Poole's website at the University of California at San Diego: http://voteview.com/. Sam Allen made adjustments to the program to fit our analysis. The procedure takes multiple binary choices for numerous decision-makers and non-parametrically infers "coordinates" for each decision-maker that yield the greatest number of correctly classified choices. In Poole and Rosenthal's example for Congress, the decision-makers are legislators and the choices are roll call votes that take the form Yea or Nay. Each legislator has an ideal coordinate within a unit hypersphere where the dimensions are arbitrarily chosen. These are not ever observed since only Yes/No votes are recorded. In our instance, the decision-makers are states, the choices are yes or no on enactment of 140 specific types of labor laws. The procedure will work with missing values, but generally this does not happen as our 48 states either had the labor legislation or did not at any given point in time.

The number of law choices determines the number of "cutting planes" through the unit hypersphere. As more laws are considered, the unit hypersphere can be divided into more 'regions' or slices. Each decision-maker is assumed to have an ideal location within the hypersphere corresponding to its ideal combination of yes/no choices. Each decision-maker is assumed to select the yes or no choice closest to its ideal coordinate. The optimal classification program developed by Poole and Rosenthal essentially 'moves' the cutting lines to create regions that minimize the number of classification errors. In this context a classification error might mean placing states that voted against mining laws with states that voted for mining laws. As the number of decisions increases, the ideal coordinates for each decision maker are measured more precisely.

Essentially, after choosing a pair of starting coordinates and two dimensions, the estimation processes each decision in an iterative fashion and estimates the coordinates for each state that minimize the number of classification errors. The number of decisions examined for each state-year was 140. After the estimation was complete the program showed the number of decisions correctly classified for each state year. The mean and median for the percentage correctly classified for the 1392 state-year observations were both 86.4 percent. The highest percentage was 97.1 (Oregon in 1901 and Arizona in 1900) and the lowest 69.3 (Washington in 1921-1924).

${ }^{25}$ The employment shares came from the occupational censuses of 1900, 1910, 1920, and 1930 with interpolations based on national employment totals between the census years.

${ }^{26}$ The data come from the Workers' Compensation data sets developed by Price Fishback and Shawn Kantor and located at Price Fishback's website at the University of Arizona Economics Department. The excel files and descriptions of the construction of and the sources of the data are provided there. The sources and data are also described in Fishback and Kantor (2000, 260-7)

${ }^{27}$ For examples of discussions of the southern legacy of slavery and the impact on southern labor markets, see Friedman (2000), Rosenbloom (2002), and Wright (1986). The south includes the following slave state members of the confederacy: Alabama, Arkansas, Florida, Georgia, Louisiana, Mississippi, North Carolina, South Carolina, Tennessee, Texas, and Virginia.

${ }^{28}$ See Mulligan and Shleifer for one argument along these lines.

${ }^{29}$ The gainfully employed in agriculture include farmers and anybody who describes themselves as gainfully employed in a farming occupation. 
${ }^{30} \mathrm{We}$ focus on the magnitude of the OSD effects in the tradition of "oomph" social science that McCloskey and Ziliak $(2004,2008)$ are working to promote. We also talk about the precision of the fit with respect to Type I error as a means of taking into the potential errors in inference that might arise when there are a small number of observations. The small number contributes to a greater likelihood of Type II error.

${ }^{31}$ For example, see Fishback (1998), Fishback and Kantor (2000), Lubove (1967), Moss (1996), Weinstein $(1967,1968)$, Wiebe (1962),

${ }^{32}$ The South was notable for having less unionization in industries where nation-wide unions were relatively strong (Friedman (2000). We have tried estimating the regressions with interaction terms between the South dummy and the Unionization index. The results changed very little and the coefficients on the interaction terms were generally small and statistically insignificant. 